Final Technical Report

\title{
Residential Fuel Cell Demonstration by the Delaware County Electric Cooperative, Inc.
}

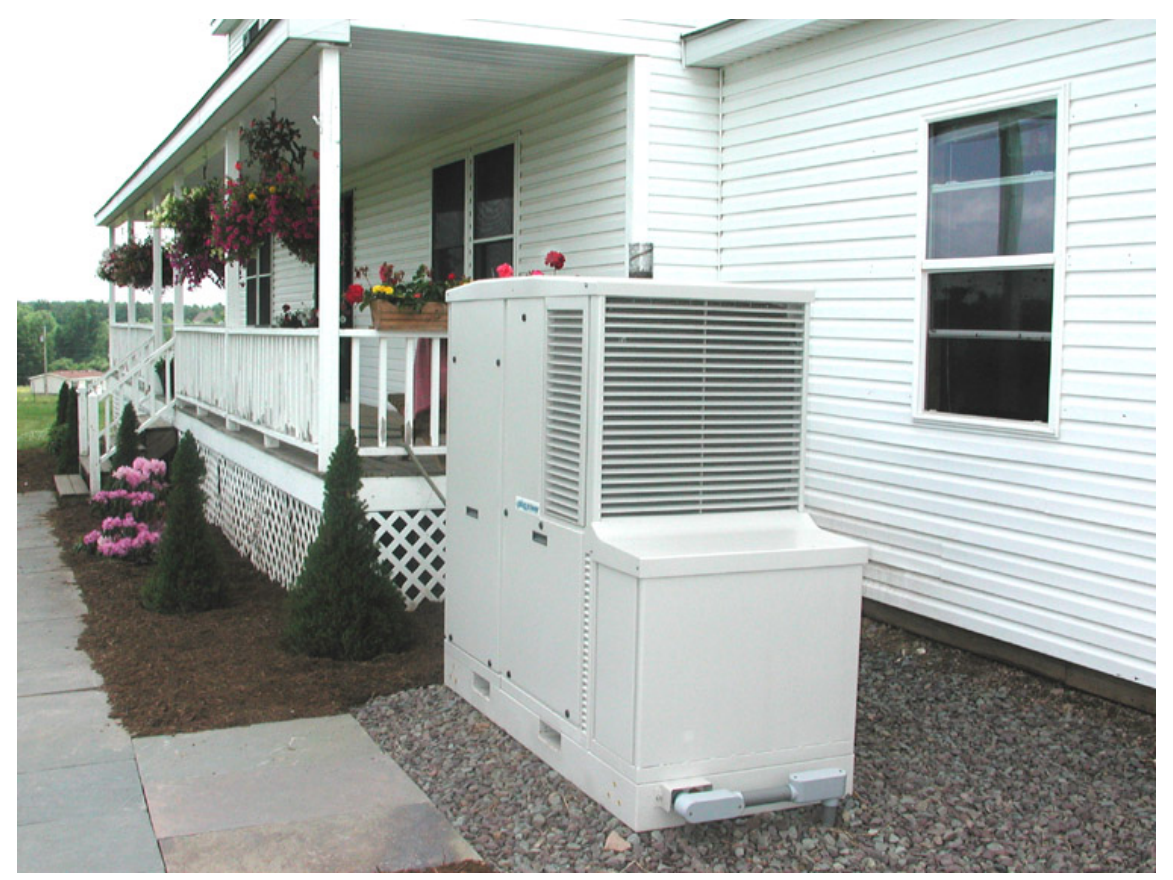

Project Ending: January 31, 2007 (official DOE end date)

Recipient: Delaware County Electric Cooperative, Inc. Award Number: DE-FC36-04G014239

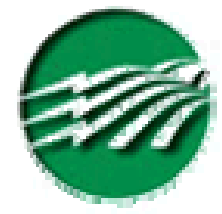

\section{Delaware County Electric} Cooperative, Inc.

This report does not contain any proprietary or confidential information. It is provided to the government with unlimited rights for disclosure, use, and reproduction. 


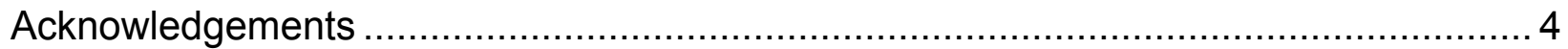

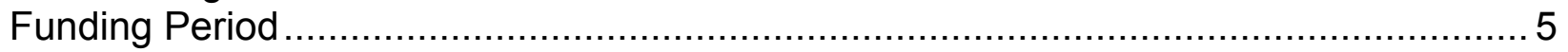

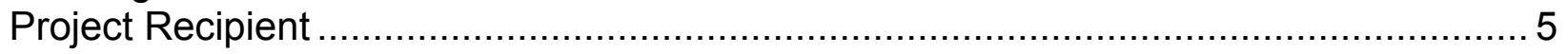

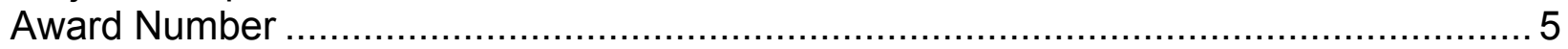

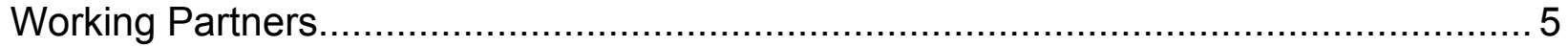

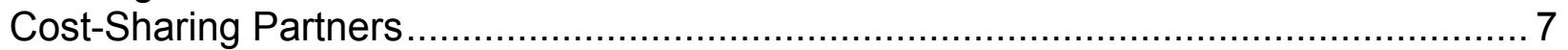

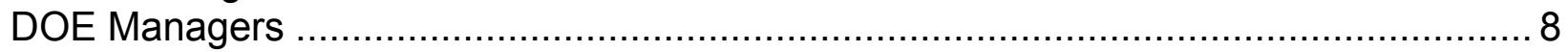

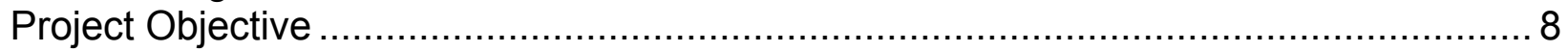

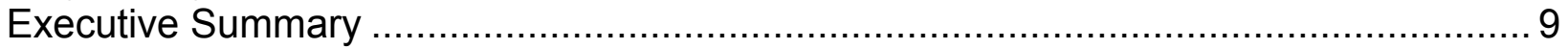

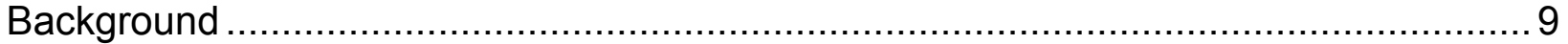

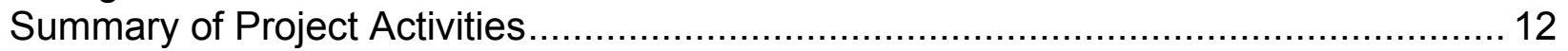

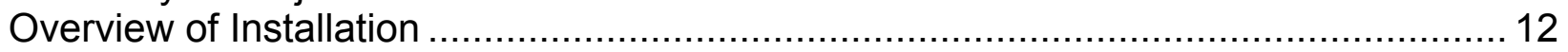

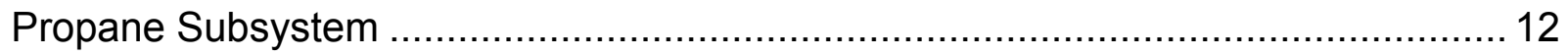

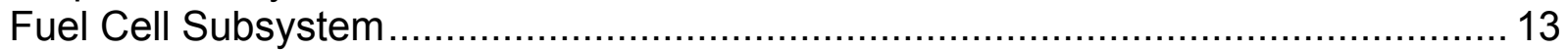

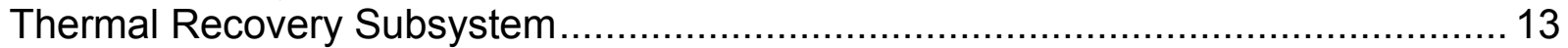

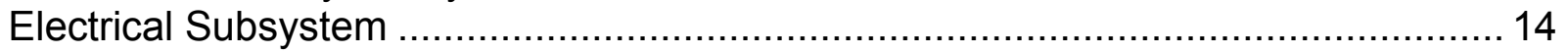

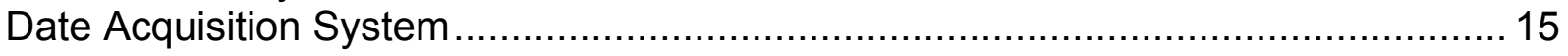

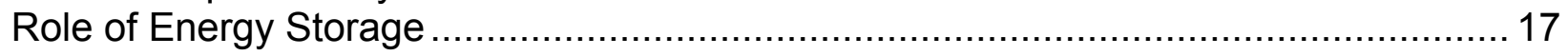

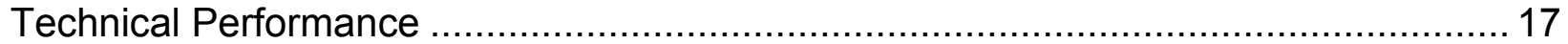

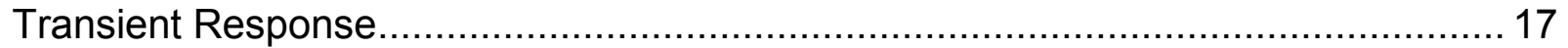

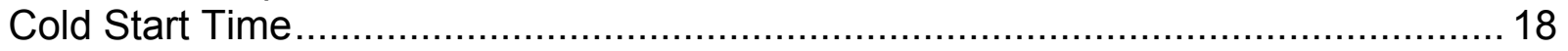

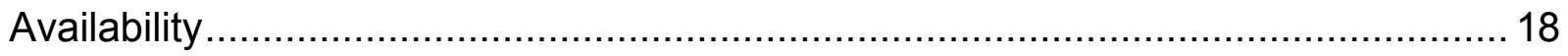

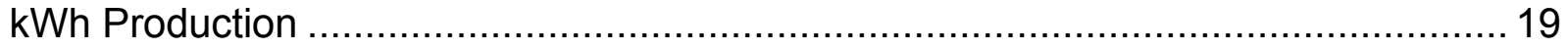

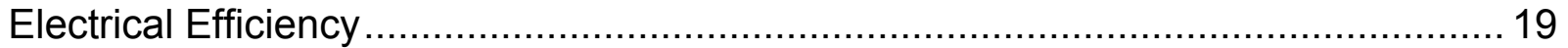

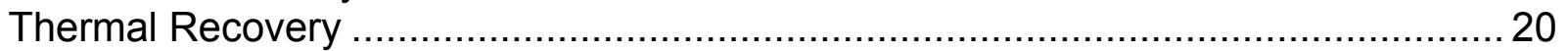

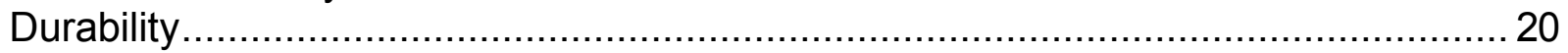

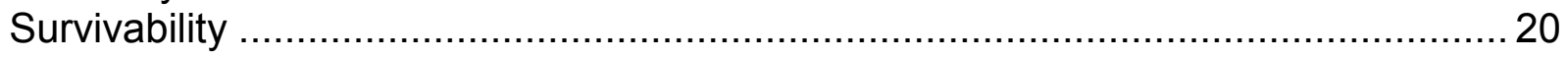

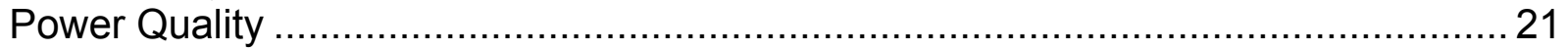

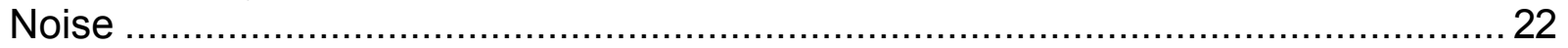

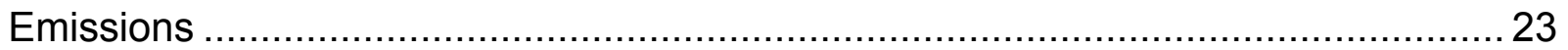

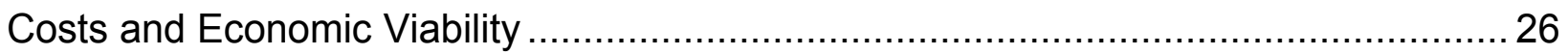

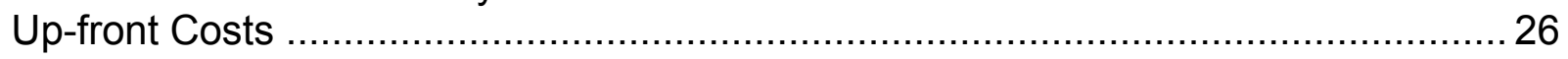

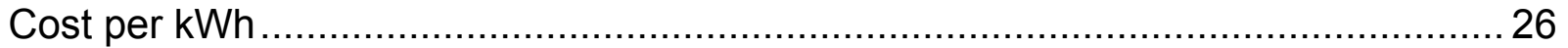

Enhanced Operations and Maintenance Concepts ......................................... 27

Existing Operations and Maintenance Documentation .................................... 27

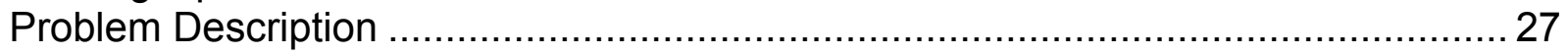

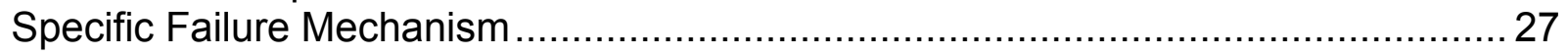

Similar Experience in other Installations .................................................... 28

Recommended Changes to Operations and Maintenance Practices ..................... 28

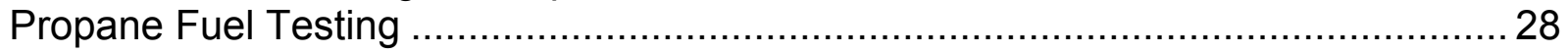

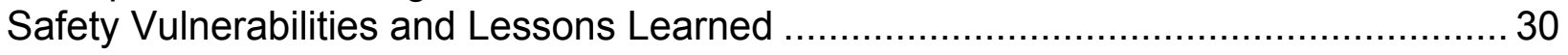

Education of State and Local Consumers ................................................. 30

Press Event and Commissioning Celebration................................................ 30

Fuel Cell and Energy Storage Educators' Seminar at SUNY Delhi ....................... 31 
Cornell Cooperative Extension Housing Tour ....................................................... 32

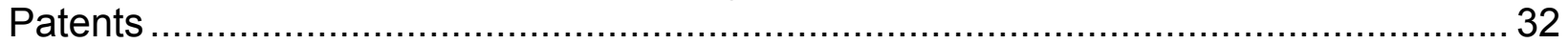

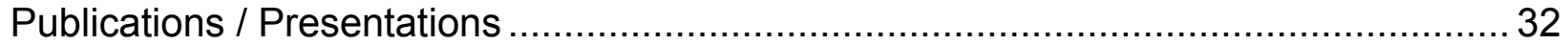

Comparison of Accomplishments to Objectives and Goals ....................................... 33

Appendix A - Demonstration Site Log................................................................ 34

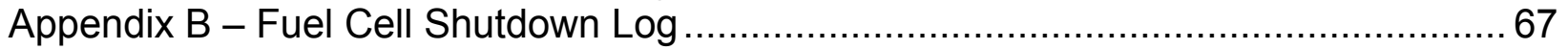




\section{Acknowledgements}

Delaware County Electric Cooperative, Inc. wishes to recognize and thank the sponsors of this demonstration project.
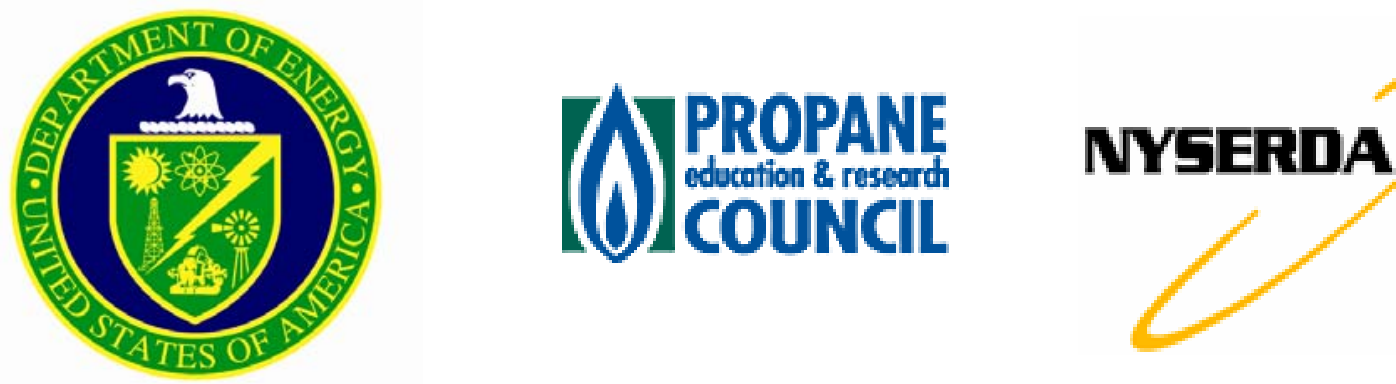

The majority of non-DCEC funds for this project were provided under contracts with the following organizations:

- Department of Energy (DOE) Golden Field Office

- NYSERDA / DOE Energy Storage Initiative ${ }^{11}$

- Propane Education and Research Council

The project team also wishes to extend our special thanks to the Board of Directors, management, and dedicated employees of the Delaware County Electric Cooperative. Without their hard work and support, the project could not have been successful.

\footnotetext{
${ }^{1}$ This project is part of the Joint Initiative between the New York State Energy Research and Development Authority (NYSERDA) and the Energy Storage Systems Program of the U.S. Department of Energy (DOE/ESS) through Sandia National Laboratories (SNL). Sandia is a multi-program laboratory operated by Sandia Corporation, a Lockheed Martin Company, for the United States Department of Energy's National Nuclear Security Administration under contract DE-AC04-94AL85000.
} 


\section{Project Title}

Residential Fuel Cell Demonstration by the Delaware County Electric Cooperative, Inc.

\section{Funding Period}

Starting October 1, 2004

Ending January 31, 2007

\section{Project Recipient}

Delaware County Electric Cooperative, Inc.

\section{Award Number}

DE-FC36-04G014239

Working Partners

\begin{tabular}{|c|c|c|}
\hline Entity & Primary Contact & Contact Information \\
\hline $\begin{array}{l}\text { New York State Energy } \\
\text { Research and } \\
\text { Development Authority } \\
\text { (NYSERDA) }\end{array}$ & $\begin{array}{l}\text { Jim Foster } \\
\text { Program Manager } \\
\text { Joe Sayer } \\
\text { Sr. Program Manager }\end{array}$ & $\begin{array}{l}17 \text { Columbia Circle } \\
\text { Albany, NY 12203-6399 } \\
\text { imf@nyserda.org } \\
\text { jhs@nyserda.org }\end{array}$ \\
\hline $\begin{array}{l}\text { Gaia Power } \\
\text { Technologies }\end{array}$ & $\begin{array}{l}\text { Ib Olsen } \\
\text { Chief Technology Officer }\end{array}$ & $\begin{array}{l}116 \text { John Street, suite } 820 \\
\text { New York, NY } 10038 \\
\text { olsenii@gaiapowertech.com } \\
(212) 732-5507 \text { phone } \\
\text { (212) } 732-5597 \text { fax }\end{array}$ \\
\hline $\begin{array}{l}\text { National Rural Electric } \\
\text { Cooperative Association } \\
\text { - Cooperative Research } \\
\text { Network (CRN) }\end{array}$ & $\begin{array}{l}\text { Bob Gibson } \\
\text { Senior Program } \\
\text { Manager }\end{array}$ & $\begin{array}{l}4301 \text { Wilson Boulevard } \\
\text { Arlington, VA } 22203 \\
\text { bob.gibson@nreca.coop } \\
\text { (703) 907-5853 phone } \\
\text { (703) } 907-5518 \mathrm{fax}\end{array}$ \\
\hline $\begin{array}{l}\text { National Propane } \\
\text { Education and Research } \\
\text { Council }\end{array}$ & $\begin{array}{l}\text { Greg Kerr } \\
\text { Director of Research } \\
\text { and Development }\end{array}$ & $\begin{array}{l}1140 \text { Connecticut Avenue, NW } \\
\text { Suite } 1075 \\
\text { Washington, DC } 20036 \\
\text { greg.kerr@propanecouncil.org } \\
\text { (202) 452-8975 phone } \\
\text { (202) 452-9054 fax }\end{array}$ \\
\hline 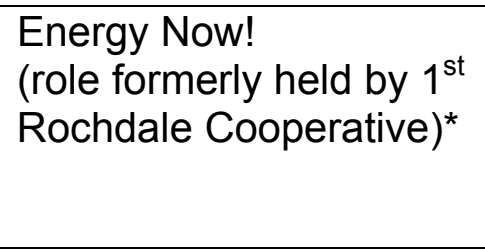 & $\begin{array}{l}\text { Tom Thompson } \\
\text { Principal }\end{array}$ & $\begin{array}{l}306 \text { Amherst Road } \\
\text { Pelham, MA 01002 } \\
\text { tomtomsun@comcast.net } \\
(413) 253-6680 \text { phone } \\
\text { (917) 886-4793 mobile }\end{array}$ \\
\hline $\begin{array}{l}\text { Sandia National } \\
\text { Laboratories }\end{array}$ & $\begin{array}{l}\text { Georgianne Peek } \\
\text { Project Manager - } \\
\text { Energy Infrastructure } \\
\text { and Dist. Energy } \\
\text { Resources } \\
\end{array}$ & $\begin{array}{l}\text { PO Box } 5800 \text { MS } 0710 \\
\text { Albuquerque, NM } 87185-0710 \\
\text { ghpeek@sandia.gov } \\
\text { (505) 844-9855 phone }\end{array}$ \\
\hline EnerNex Corporation & Jeffrey Lamoree & 144-E Market Place Boulevard \\
\hline
\end{tabular}




\begin{tabular}{|c|c|c|}
\hline & President & $\begin{array}{l}\text { Knoxville, TN 37922-2337 } \\
\text { jeff@enernex.com } \\
(865) 691-5540 \times 131 \text { phone } \\
\text { (865) 691-5046 fax }\end{array}$ \\
\hline Mirabito Fuel Group & $\begin{array}{l}\text { Wayne Davis } \\
\text { General Manager - } \\
\text { Propane Products }\end{array}$ & $\begin{array}{l}3212 \text { Old Vestal Road } \\
\text { Vestal, NY } 13850 \\
\text { wayne.davis@mirabito.com } \\
(607) 729-6680 \text { phone } \\
(607) 729-6931 \text { fax }\end{array}$ \\
\hline Plug Power, Inc. & $\begin{array}{l}\text { Vinny Cassala } \\
\text { Customer Relationship } \\
\text { Manager }\end{array}$ & $\begin{array}{l}968 \text { Albany-Shaker Road } \\
\text { Latham, NY } 12110 \\
\text { vincent cassala@plugpower.com } \\
\text { (518) 782-7700 x1228 phone } \\
\text { (518) 782-7909 fax }\end{array}$ \\
\hline $\begin{array}{l}\text { New York Power } \\
\text { Authority }\end{array}$ & $\begin{array}{l}\text { Guy Sliker } \\
\text { Research and } \\
\text { Development } \\
\text { Technology }\end{array}$ & $\begin{array}{l}23 \text { Main Street } \\
\text { White Plains, NY } 10601.3170 \\
\text { guy.sliker@nypa.gov } \\
\text { (914) 287-3792 phone } \\
\text { (914) 681-6860 fax }\end{array}$ \\
\hline $\begin{array}{l}\text { State University of New } \\
\text { York College of } \\
\text { Technology at Delhi }\end{array}$ & $\begin{array}{l}\text { David Addison } \\
\text { Dean of the Technology } \\
\text { Division }\end{array}$ & $\begin{array}{l}\text { SUNY Delhi } \\
2 \text { Main St. } \\
\text { Delhi, NY } 13753 \\
\text { addisodb@delhi.edu } \\
\text { (607) 746-4070 phone }\end{array}$ \\
\hline
\end{tabular}

*Due to financial conditions unrelated to the project, former partner $1^{\text {st }}$ Rochdale Cooperative has transferred its NYSERDA contract and the incumbent cost-sharing responsibilities to Energy Now, Inc., owned and managed by former $1^{\text {st }}$ Rochdale Cooperative employee Tom Thompson. 
Cost-Sharing Partners

\begin{tabular}{|c|c|c|}
\hline Entity & Primary Contact & Contact Information \\
\hline $\begin{array}{l}\text { New York State Energy } \\
\text { Research and } \\
\text { Development Authority } \\
\text { (NYSERDA) }\end{array}$ & $\begin{array}{l}\text { Jim Foster } \\
\text { Program Manager } \\
\text { Joe Sayer } \\
\text { Sr. Program Manager }\end{array}$ & $\begin{array}{l}17 \text { Columbia Circle } \\
\text { Albany, NY 12203-6399 } \\
\text { imf@nyserda.org } \\
\text { ihs@nyserda.org }\end{array}$ \\
\hline Gaia Power Technologies & $\begin{array}{l}\text { Ib Olsen } \\
\text { Chief Technology Officer }\end{array}$ & $\begin{array}{l}116 \text { John Street, suite } 820 \\
\text { New York, NY } 10038 \\
\text { olsenii@gaiapowertech.com } \\
\text { (212) 732-5507 phone } \\
\text { (212) 732-5597 fax }\end{array}$ \\
\hline $\begin{array}{l}\text { National Rural Electric } \\
\text { Cooperative Association } \\
\text { - Cooperative Research } \\
\text { Network (CRN) }\end{array}$ & $\begin{array}{l}\text { Bob Gibson } \\
\text { Senior Program Manager }\end{array}$ & $\begin{array}{l}4301 \text { Wilson Boulevard } \\
\text { Arlington, VA } 22203 \\
\text { bob.gibson@nreca.coop } \\
\text { (703) 907-5853 phone } \\
\text { (703) } 907-5518 \text { fax }\end{array}$ \\
\hline $\begin{array}{l}\text { Propane Education and } \\
\text { Research Council }\end{array}$ & $\begin{array}{l}\text { Greg Kerr } \\
\text { Director of Research and } \\
\text { Development }\end{array}$ & $\begin{array}{l}1140 \text { Connecticut Avenue, NW } \\
\text { Suite } 1075 \\
\text { Washington, DC } 20036 \\
\text { greg.kerr@propanecouncil.org } \\
\text { (202) 452-8975 phone } \\
\text { (202) 452-9054 fax }\end{array}$ \\
\hline $\begin{array}{l}\text { Energy Now! } \\
\text { (role formerly held by } 1^{\text {st }} \\
\text { Rochdale Cooperative) }\end{array}$ & $\begin{array}{l}\text { Tom Thompson } \\
\text { Principal }\end{array}$ & $\begin{array}{l}306 \text { Amherst Road } \\
\text { Pelham, MA } 01002 \\
\text { tomtomsun@,comcast.net } \\
\text { (413) 253-6680 phone } \\
\text { (917) 886-4793 mobile }\end{array}$ \\
\hline
\end{tabular}


DCEC Contact:

\begin{tabular}{|l|l|l|}
\hline Delaware County Electric & Mark Hilson Schneider & 39 Elm Street \\
Cooperative, Inc. & Engineering Manager & $\begin{array}{l}\text { PO Box 471 } \\
\text { Delhi, NY 13753 } \\
\text { mark.schneider@dce.coop }\end{array}$ \\
& & $\begin{array}{l}\text { (607) 746-9297 phone } \\
(607) 746-7548 \text { fax }\end{array}$ \\
\hline & 39 Elm Street \\
& Go Box 471 \\
& General Manager / CEO & Delhi, NY 13753 \\
& & greg.starheim@dce.coop \\
& & $(607)$ 746-2341 phone \\
& & \\
& & \\
\hline
\end{tabular}

DOE Managers

\begin{tabular}{|l|l|l|}
\hline $\begin{array}{l}\text { Department of Energy } \\
\text { HQ, Washington, DC }\end{array}$ & $\begin{array}{l}\text { Kathi Epping } \\
\text { Technical Manager }\end{array}$ & $\begin{array}{l}1000 \text { Independence Ave., SW } \\
\text { Washington, DC 20585 } \\
\text { kathi.epping@ee.doe.gov } \\
\text { (202) 586-7425 phone }\end{array}$ \\
\hline $\begin{array}{l}\text { Department of Energy } \\
\text { Golden Field Office }\end{array}$ & $\begin{array}{l}\text { Reg Tyler } \\
\text { Program Engineer }\end{array}$ & $\begin{array}{l}\text { Golden Field Office } \\
1617 \text { Cole Boulevard } \\
\text { Golden, CO 80401-3393 } \\
\end{array}$ \\
& & $\begin{array}{l}\text { reginald.tyler@go.doe.gov } \\
\text { (303) 275-4929 phone } \\
\text { (303) 275-4753 fax }\end{array}$ \\
\hline
\end{tabular}

\section{Project Objective}

This project will demonstrate the viability of grid-independent operation of a typical upstate NY home whose total electrical energy needs will be met by a propane fueled fuel cell. The demonstration will combine intelligently managed energy storage, inhome load control, and combined heat and power to optimize the performance of the fuel cell as a whole-home energy source. The project will contribute to enhanced awareness and knowledge among consumers, rural electric cooperatives, fuel cell manufacturers, energy storage manufacturers, educators, and staff members of national agencies and laboratories through a process including public awareness events, publications, educational programs, and technology transfer. The project will validate the following objectives of propane fueled hydrogen fuel cells for edge-of-grid residences:

- measure and report technical performance

- provide raw cost data and economic viability analysis

- document maintenance and operations concept enhancements specific to residential fuel cells

- share safety related vulnerabilities analysis and lessons learned

- promote education of state and local consumers. 


\section{Executive Summary}

This demonstration project contributes to the knowledge base in the area of fuel cells in stationary applications, propane fuel cells, edge-of-grid applications for fuel cells, and energy storage in combination with fuel cells.

The project demonstrated that it is technically feasible to meet the whole-house electrical energy needs of a typical upstate New York residence with a 5-kW fuel cell in combination with in-home energy storage without any major modifications to the residence or modifications to the consumption patterns of the residents of the home.

The use of a fuel cell at constant output power through a 120-Volt inverter leads to system performance issues including:

- relatively poor power quality as quantified by the IEEE-defined short term flicker parameter

- relatively low overall system efficiency

Each of these issues is discussed in detail in the text of this report.

The fuel cell performed well over the 1-year demonstration period in terms of availability and efficiency of conversion from chemical energy (propane) to electrical energy at the fuel cell output terminals. Another strength of fuel cell performance in the demonstration was the low requirements for maintenance and repair on the fuel cell.

The project uncovered a new and important installation consideration for propane fuel cells. Alcohol added to new propane storage tanks is preferentially absorbed on the surface of some fuel cell reformer de-sulfurization filters. The experience on this project indicates that special attention must be paid to the volume and composition of propane tank additives. Size, composition, and replacement schedules for the desulfurization filter bed should be adjusted to account for propane tank additives to avoid sulfur contamination of fuel cell stacks.

Despite good overall technical performance of the fuel cell and the whole energy system, the demonstration showed that such a system is not economically feasible as compared to other commercially available technologies such as propane reciprocating engine generators.

\section{Background}

The project was conceived as a means to help overcome the DOE technical barriers for fuel cell validation and simultaneously test the hypothesis that propane-fueled fuel cells can become a practical alternative to costly primary power line extensions to serve extremely rural residences. As shown in Figure 1, this fuel cell and energy storage demonstration project serves the objectives of the DOE, NRECA, and DCEC. 


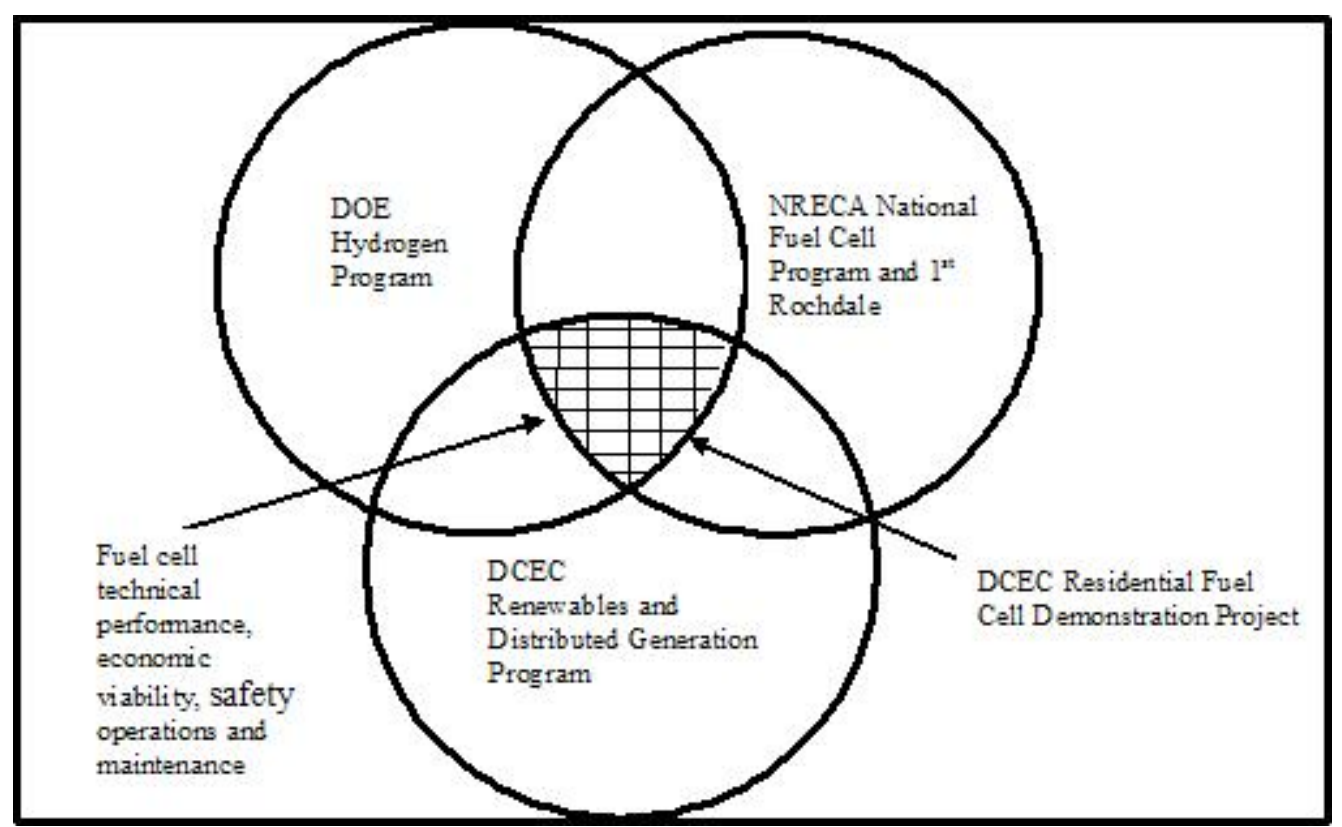

Figure 1 Intersection of Common Objectives Among DOE, NRECA, and DCEC

The relevant DOE hydrogen and electricity co-production technical barriers include the following:

- Cost and durability not statistically validated

- Permitting, codes, and standards not established for fuel cells in or around buildings

- Lack of operational and maintenance experience.

Although this is a one-year fuel cell project, DCEC has been collecting base load data at the demonstration site for the past three years using 15-minute averaged data supplied by DCEC's automated meter reading system. Figures 2 and 3 display summaries of the home's peak demand and energy consumption data from May 2002 through January 2005. 
DE-FC36-04G014239

Delaware County Electric Cooperative, Inc.

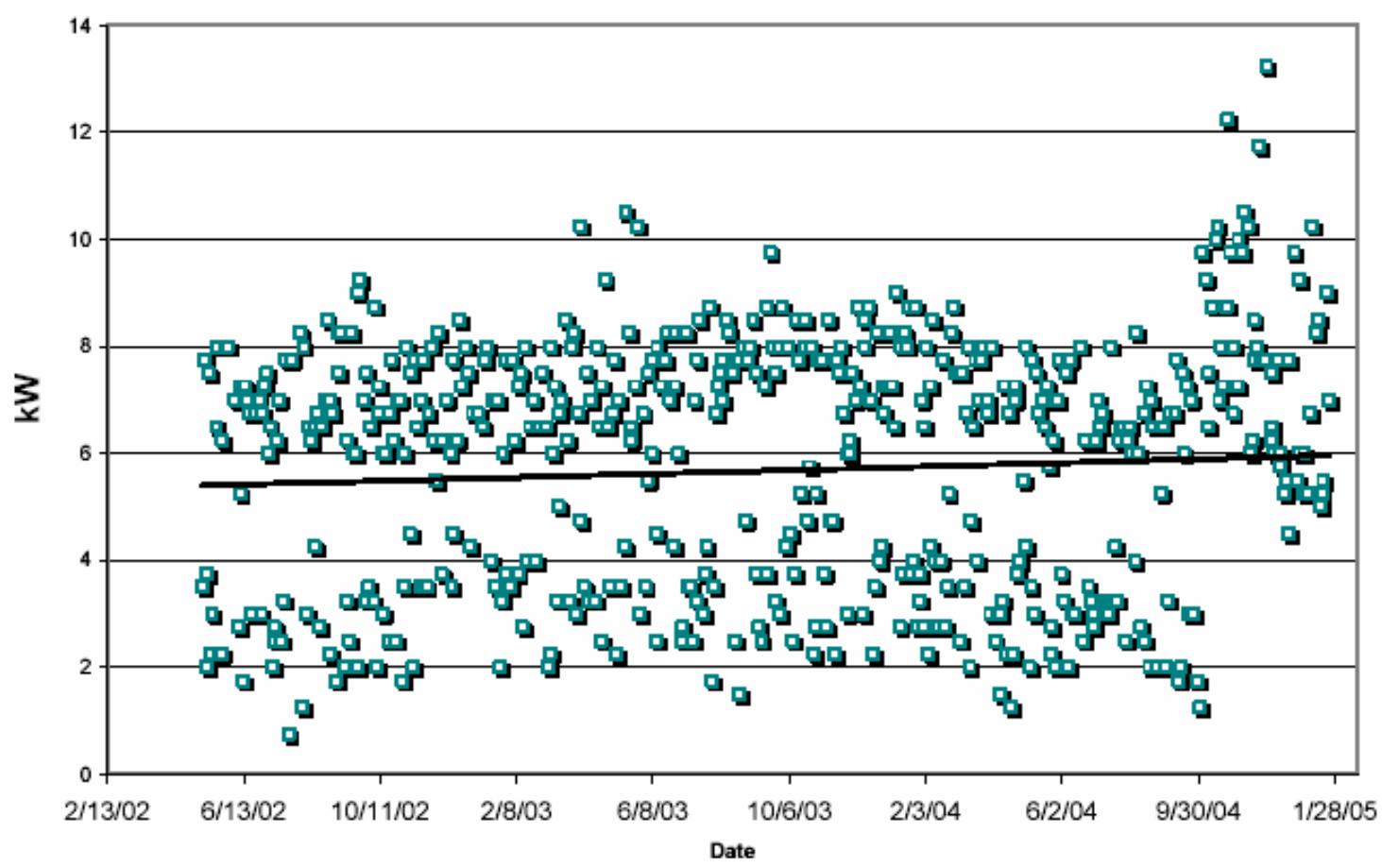

Figure 2 Historical Peak Power Demand for Fuel Cell Host Residence

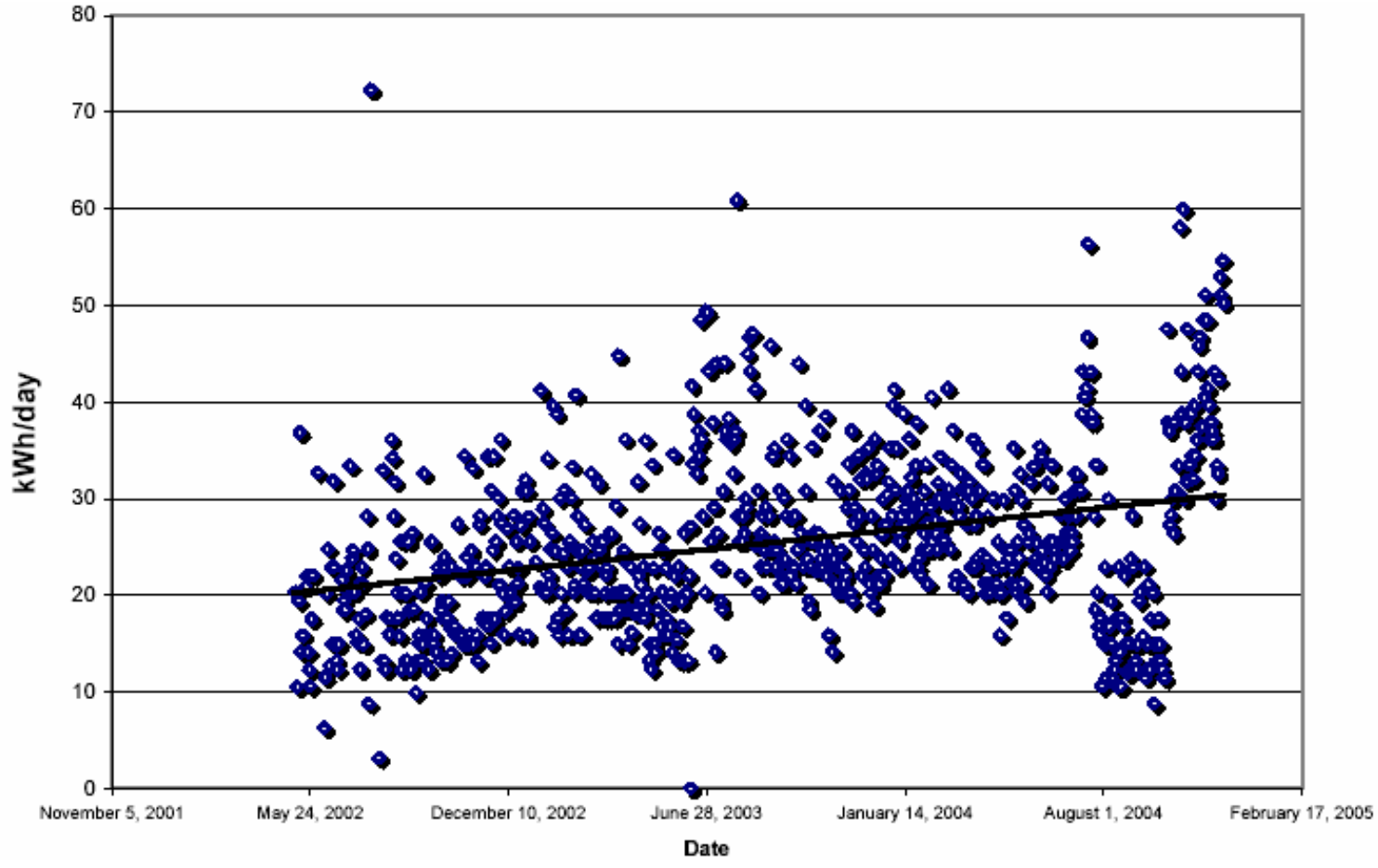

Figure 3 Historical Daily Energy Consumption for Fuel Cell Host Residence

Based on the historical data, the host residence is trending toward higher peak demands and energy consumption. The addition of a hot tub at the residence during 2004 is responsible for much of that upward trend. Peak power consumption was measured to be approximately $13.5 \mathrm{~kW}$ using energy consumed during a moving 15- 
minute window to calculate power. Average power consumption has been below 1.5 $\mathrm{kW}$ over the three year data collection period, but appears to be approximately $2 \mathrm{~kW}$ in recent months. As this data demonstrates, a typical upstate NY residence has been selected for the demonstration, which serves as a challenging testing ground for the combination of fuel cell and energy storage.

\section{Summary of Project Activities}

DCEC installed a propane fuel cell and energy storage system at the demonstration site in May of 2005, commissioned the equipment in June of 2005, and began a 1-year demonstration period on July 5, 2005. During the 1-year demonstration period, DCEC collected performance data, conducted education and outreach events that utilized the demonstration site, performed and documented the maintenance activities required to operate the fuel cell, and performed additional testing in order to fully characterize the technical performance and economic viability of the installation. Following completion of the 1-year demonstration period, DCEC and its partners have continued to analyze and report on the demonstration project at a number of academic and industry events throughout the United States.

\section{Overview of Installation}

The installation consisted of several major subsystems:

- Propane storage, metering, and delivery piping

- Fuel cell

- Thermal recovery system

- Electrical system including electrical energy storage

- Data acquisition system

\section{Propane Subsystem}

The propane subsystem consisted of a 1000 gallon underground storage tank, buried pipe to deliver the propane to the load, pressure regulation, and a pulse-producing propane meter. In the picture below, an employee of project partner Mirabito Fuel Group is preparing terminations on the pedestal that supported the propane meter and pressure regulator, which was positioned between the underground storage tank and the fuel cell. 


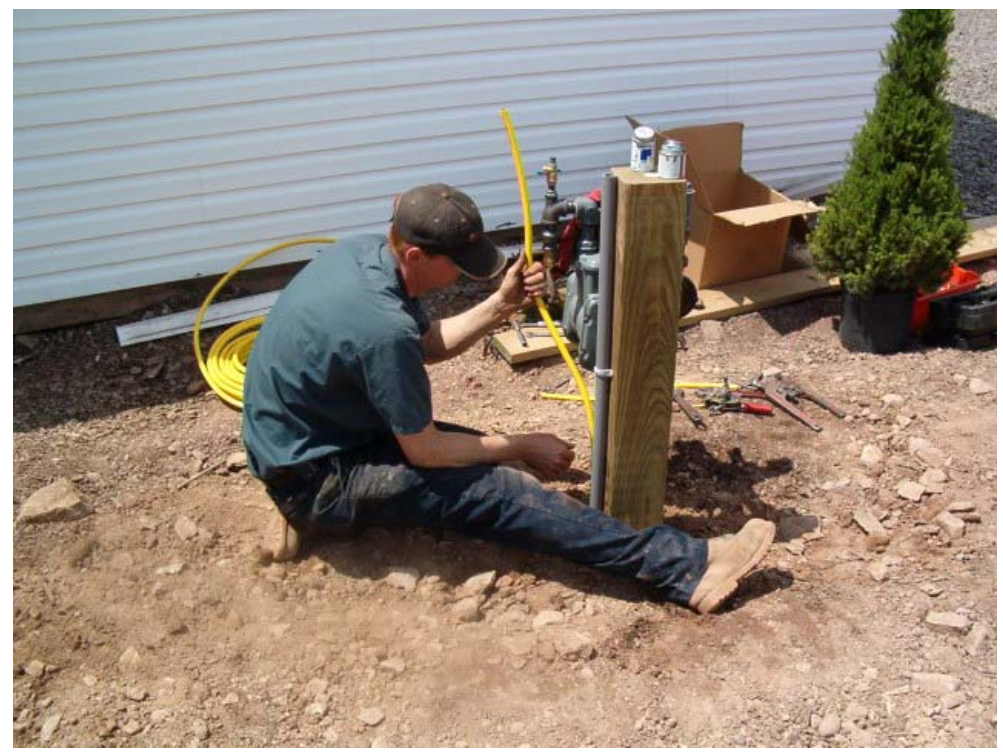

Fuel Cell Subsystem

The fuel cell was a Plug Power GenSys propane fuel cell with $5 \mathrm{~kW}$ maximum sustained output. The fuel cell was delivered from the manufacturer with a self contained reformer, cell stack, inverter, controller, and battery for black start. The picture below shows the fuel cell being moved into place by DCEC personnel using a leased skid steerer.

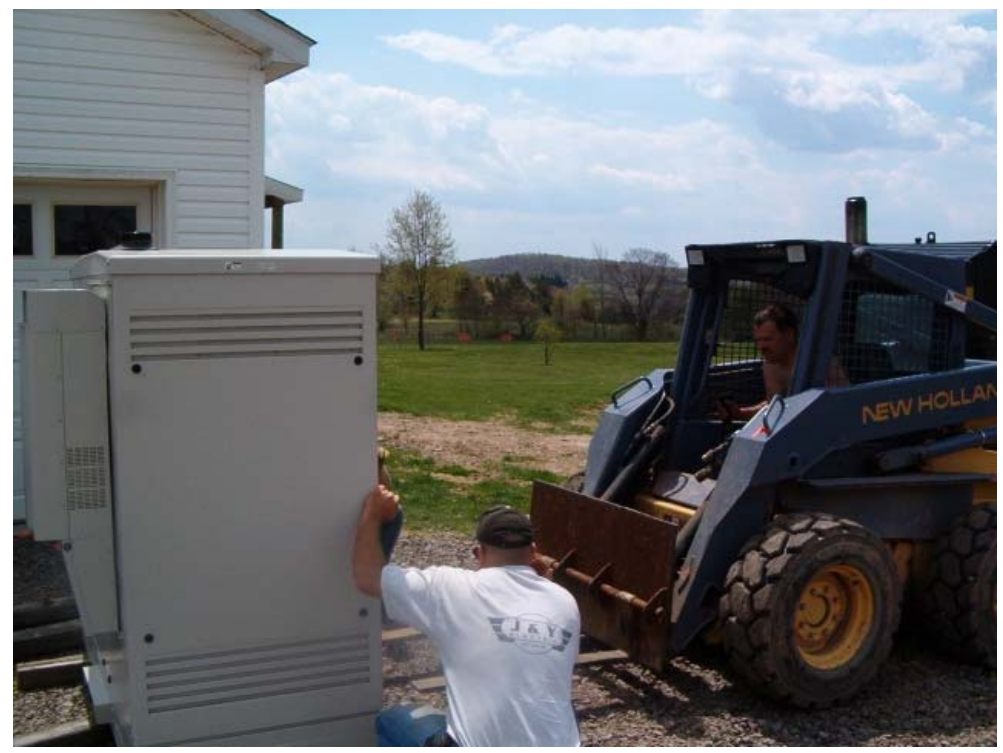

Thermal Recovery Subsystem

The thermal recovery subsystem consisted of a thermal recovery loop that circulated a glycol/water mixture between the fuel cell and the residence's utility room. There were two thermal loads that were capable of pulling heat from the thermal recovery loop:

1. a tank-type heat exchanger that pre-heated domestic hot water before entering a traditional hot water heater 
2. a length of baseboard radiators in the basement of the residence through which the glycol/water mixture flowed

When the thermal recovery system was in its normal state, the glycol/water mixture would circulate through the hot water heat exchanger to preheat the domestic hot water. When the thermostat in the basement called for heat, a diverter valve caused the glycol/water mixture to flow through the baseboard heaters instead of the heat exchanger. The picture below shows employees of Dubben Brothers Plumbing service installing the baseboard heaters in the basement. Due to the fact that the thermal recovery loop operated at temperatures lower than typical baseboard heating applications, very long sections of baseboard radiators were installed in order to get sufficient heat transfer into the room.

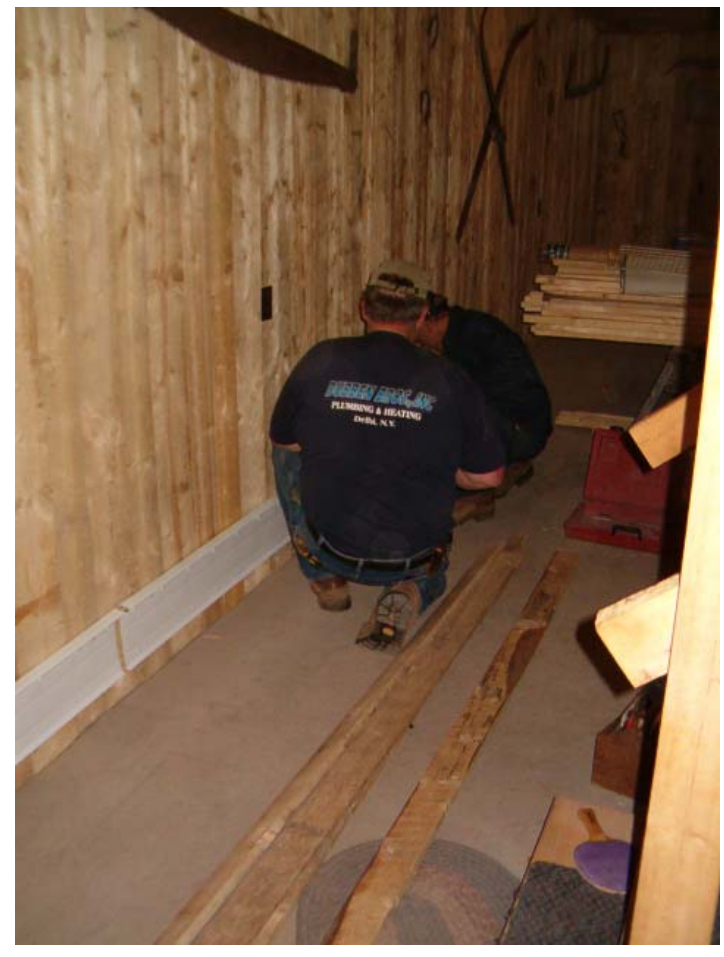

\section{Electrical Subsystem}

The electrical subsystem consisted of the following components:

- an electrical energy storage system from Gaia Power Technologies

- a transformer to take a single phase $120-$ Volt input and provide a split phase 240-Volt output

- a controllable transfer switch to switch between the local generation input (fuel cell and energy storage) and the utility grid input

- a set of load control relays that were controlled by the Gaia controller and interrupted large loads (e.g., hot tub heater) when the total home load was greater than the capacity of the local generation system could support

During most of the demonstration period, the fuel cell was operated at a steady output between 1.5 and $2 \mathrm{~kW}$. The output from the fuel cell was either used in real time by the electrical load of the home or it was used to charge the batteries in the 
energy storage system. The graphic below is a schematic representation of the electrical subsystem.

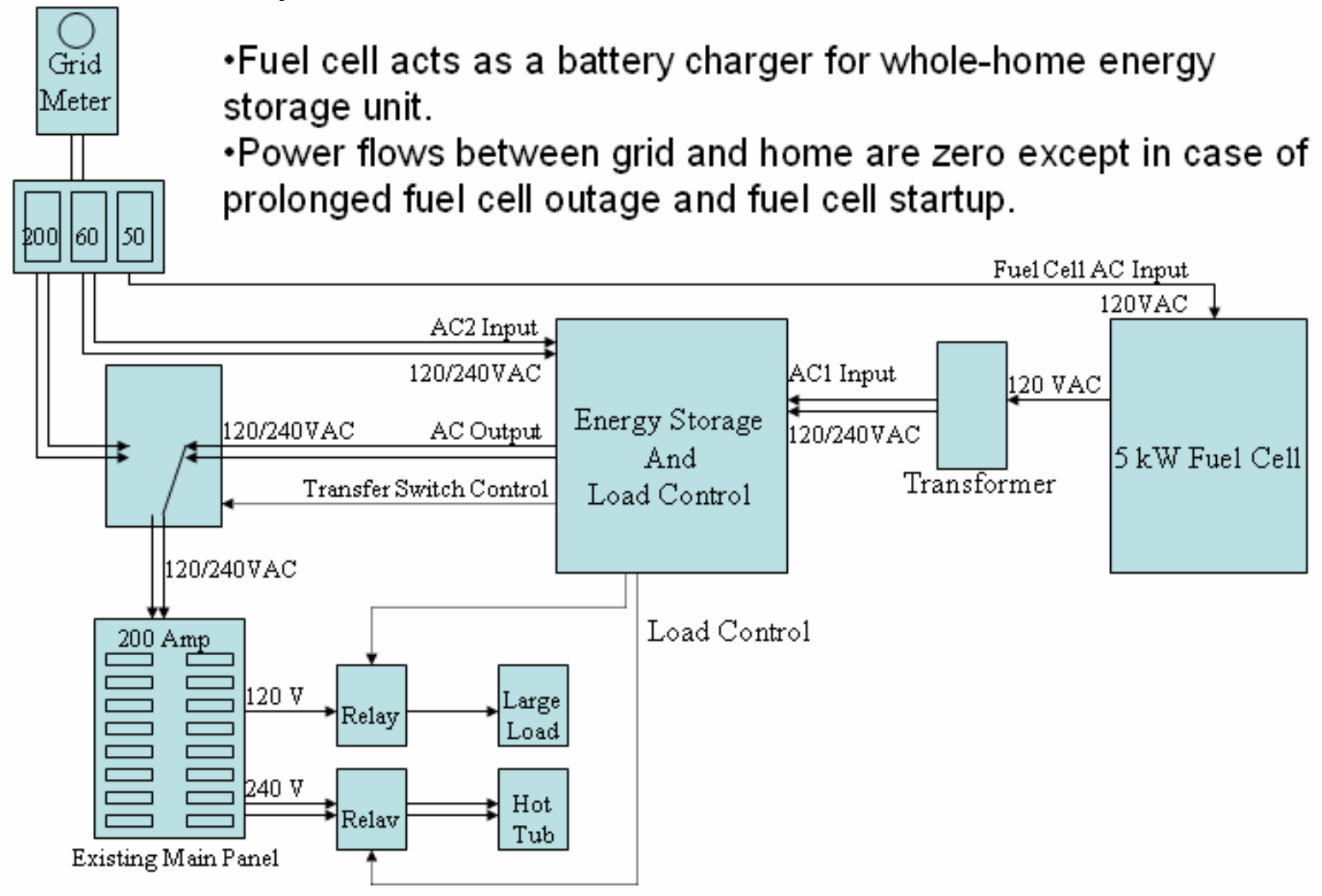

Date Acquisition System

The data acquisition system monitored and recorded the following information in real time:

- true RMS current and voltage on both legs of the fuel cell feed into the energy storage device and the consumption at the home's main panel

- temperatures on the inlet and outlet of the thermal recovery loop

- flow in the thermal recovery loop

- ambient conditions outside the home

- internal fuel cell settings, self-reported fuel consumption, and self-reported electrical output

- internal energy storage device settings, self-reported battery charge state, and self-reported power flows in and out of the batteries

- propane meter pulse counts

The graphic below is a schematic representation of the data acquisition system employed at the demonstration site. 


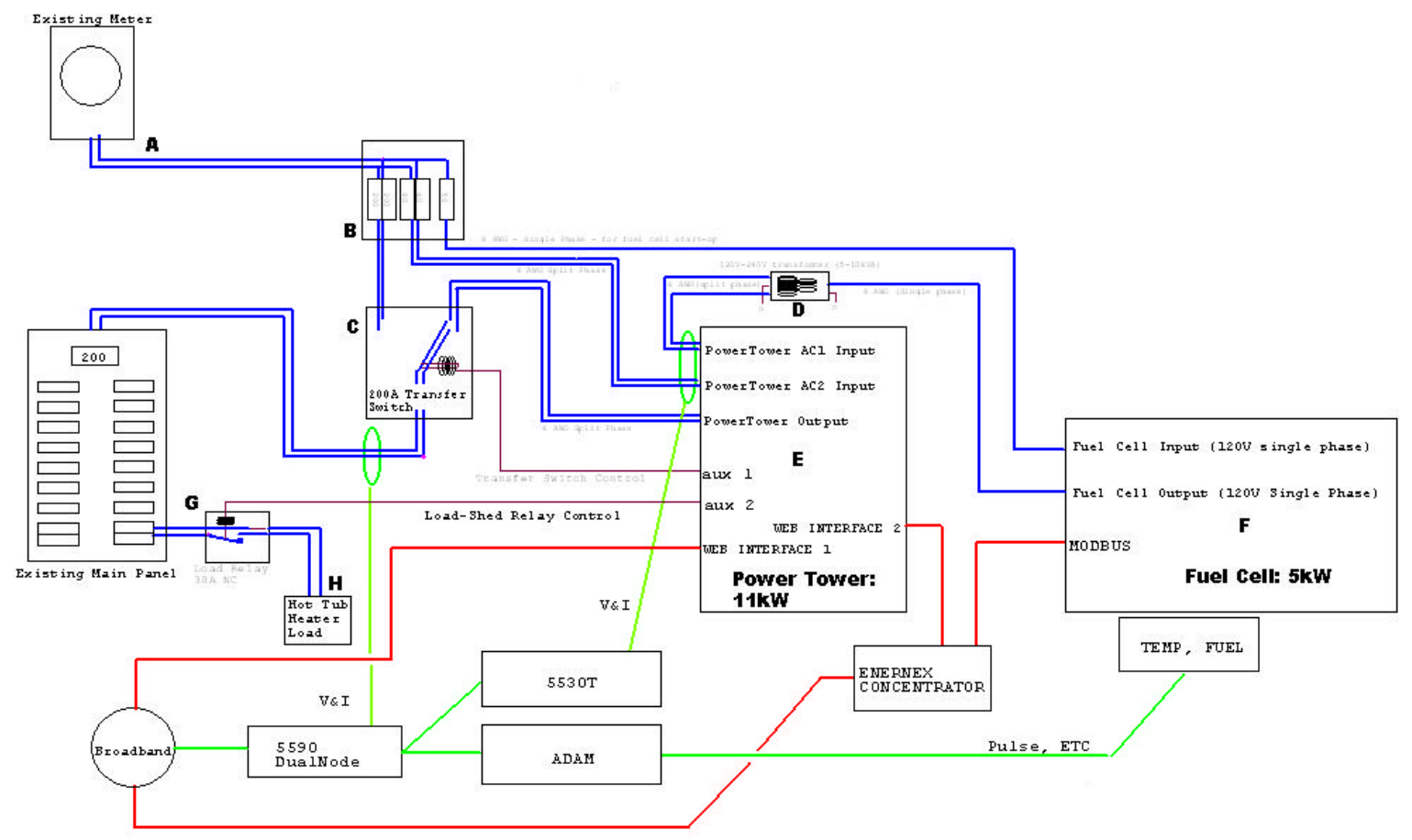

Due to the remote setting of the demonstration residence, a satellite internet connection was installed to facilitate data transfer of the monitored parameters to project partners. The data was made available to the public in real time and for downloading of historical data at the DOE/NYSERDA web page hosted by EnerNex Corporation:

http://www.storagemonitoring.com/nyserda-doe/fuelcell.shtml. Historical data will continue to be available on the EnerNex web site for some time into the future. The picture below shows the DOE/NYSERDA web site where project data is available for viewing, graphing, and downloading in comma separated text format.
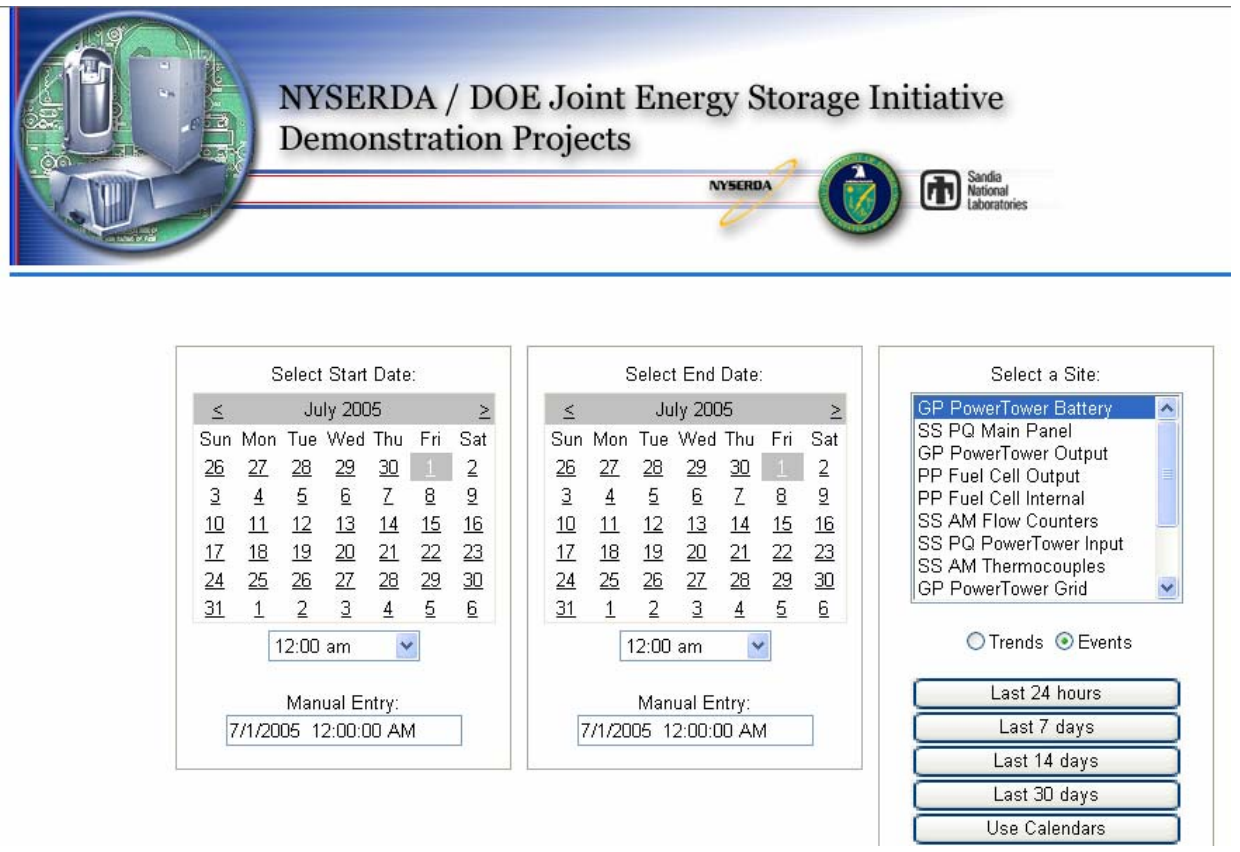


\section{Role of Energy Storage}

It would be impossible for DCEC to utilize a fuel cell to serve the energy needs of an offgrid residence without using energy storage. Three forms of energy storage were used for the demonstration:

1. Chemical energy storage in propane

The 1000-gallon propane tank was a convenient, clean, and energy-dense means to store enough energy to meet approximately 6 months of the residential need.

2. Electrical energy storage in batteries

The lead-acid batteries were essential to handle the non-dipatchable, constant output of the fuel cell and respond to the peaks and valleys of the residential electric load.

3. Thermal energy storage in a hot water tank

The thermal energy storage in the hot water heat exchanger tank allowed heat to be captured opportunistically as available from the fuel cell. The captured heat could then be made available to the domestic hot water supply as hot water was used in the home.

\section{Technical Performance}

\section{Transient Response}

The figure below shows a power quality recording of the input to the energy storage device while it is being fed by the fuel cell through a split phase transformer (120 V $120 / 240 \mathrm{~V}$ ) in response to a large step function in current.
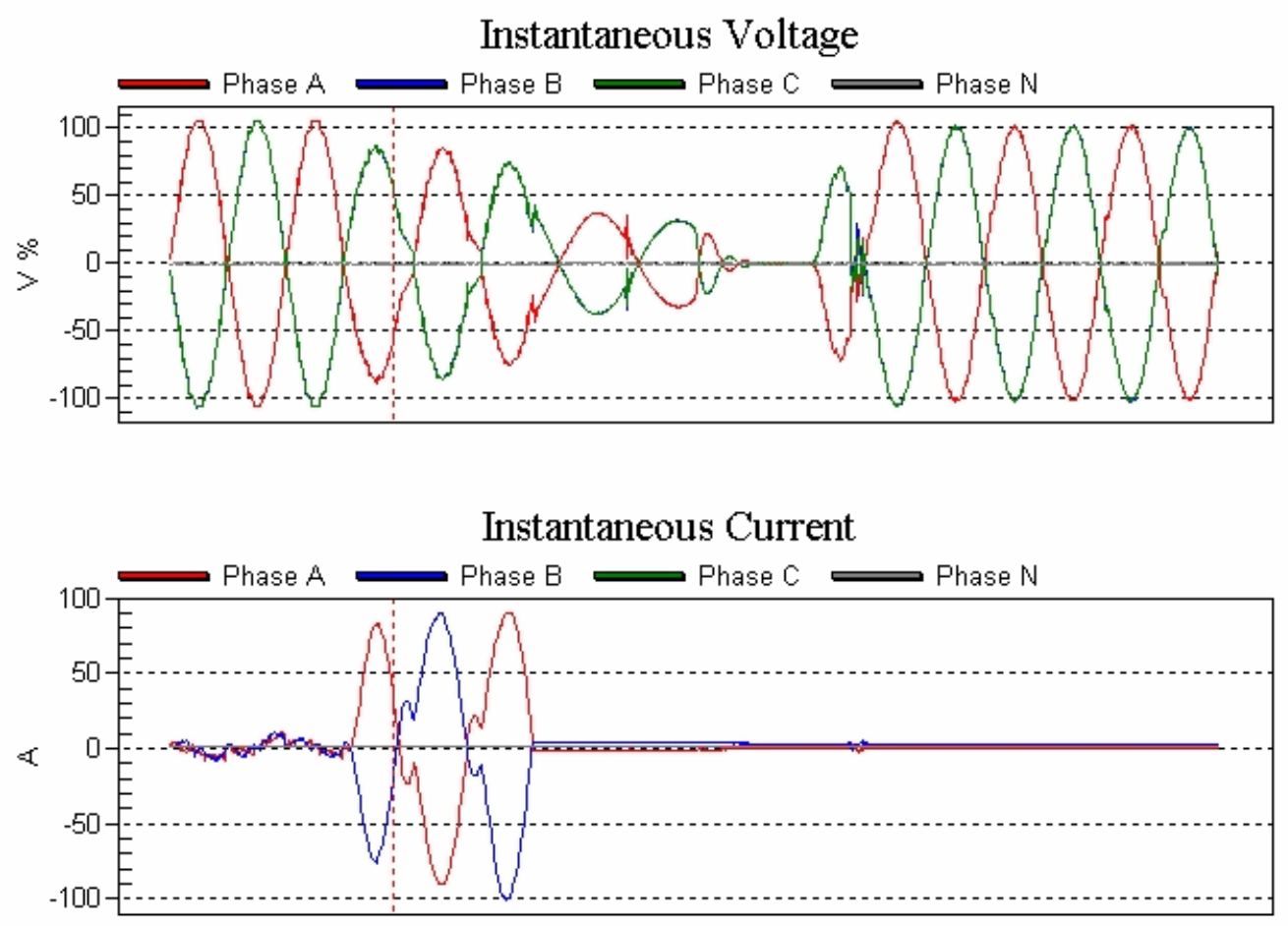
The fuel cell's response to the step function current demand is typical of a weak distributed generation source. This data capture is typical of the recordings of many similar power quality "events" that occurred during the 1-year demonstration period. This recording and many others are available at the project data clearinghouse website hosted by EnerNex Corporation at http://www.storagemonitoring.com/nyserda-doe/. Other forms of power quality events captured and available on the website include instantaneous swells, transients, instantaneous sags, and temporary interruptions.

\section{Cold Start Time}

A cold start timed test was performed on June 21, 2005 during the installation and commissioning period. The start-up time commenced when the start button on the fuel cell was pressed and ended when the fuel cell entered the full running state, meaning that the reformer, stack, and system are all in their running states. The cold start time was measured to be 3 hours and 19 minutes.

\section{Availability}

The Plug Power GenSys $5 \mathrm{~kW}$ propane fuel cell was running and providing power $71.8 \%$ of the one-year demonstration period. The figure below shows the periods during which the fuel cell was running and when the fuel cell was off. The fuel cell was run at all times when it was available to run, so percent run time is equivalent to percent availability in this case.

\section{Running / Off Status}

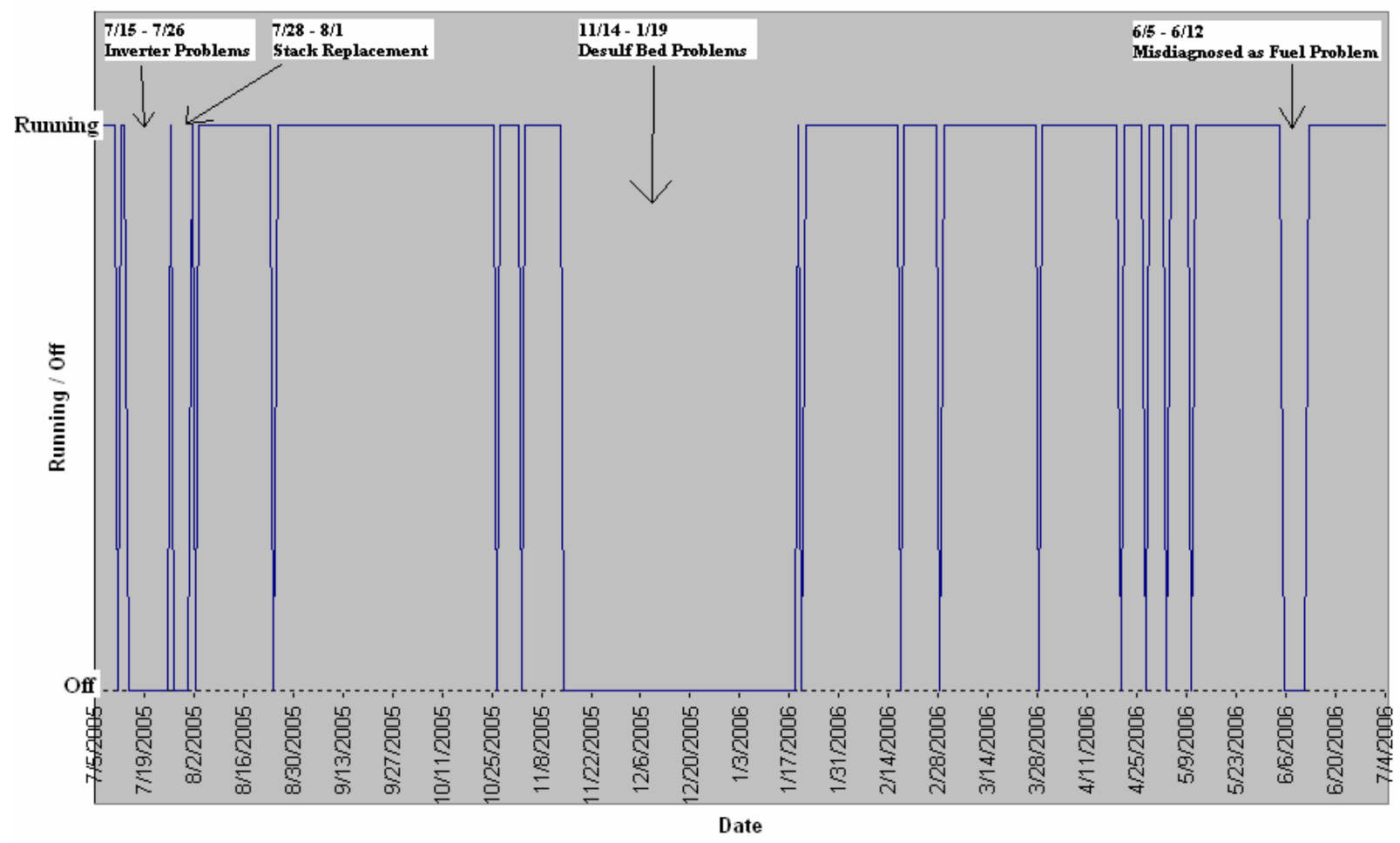


The fuel cell shut down a total of twenty-four (24) times during the 1-month commissioning period and the 1-year demonstration period. Appendix B to this report lists each of the 24 shutdowns, the error message associated with the shutdown, the time to recover from the shutdown, and any intervention required in order to restore the fuel cell to an operating state. There were only four periods during the 1-year demonstration period during which the fuel cell was unavailable for more than 1 day. Each of those outages lasting more than 1 day is noted on the figure above.

The table below summarizes the outages and the actions that were required to recover from outages.

\begin{tabular}{|l|c|}
\hline \multicolumn{1}{|c|}{ Outage Recovery Type } & $\begin{array}{c}\text { Number of Occurrences } \\
\text { in 13 Months }\end{array}$ \\
\hline $\begin{array}{l}\text { Auto restart by the fuel cell with no intervention by } \\
\text { a human or external control system }\end{array}$ & 10 \\
\hline $\begin{array}{l}\text { Repair or maintenance requiring human } \\
\text { intervention }\end{array}$ & 8 \\
\hline $\begin{array}{l}\text { Manual restart requiring human intervention, but no } \\
\text { repair or maintenance required }\end{array}$ & $5^{*}$ \\
\hline $\begin{array}{l}\text { No restart occurred because the fuel cell } \\
\text { demonstration period was complete }\end{array}$ & 1 \\
\hline
\end{tabular}

*The manual restart count of 5 includes 2 manual starts that followed planned shutdowns during the installation and commissioning process.

kWh Production

Over the course of the demonstration period, the fuel cell produced a total of 10,940 $\mathrm{kWh}$ of energy. Dividing the number of $\mathrm{kWh}$ produced by the number of running hours for the fuel cell gives a value of $1.75 \mathrm{~kW}$ average production level. The fuel cell was most frequently set at an output setting of $2 \mathrm{~kW}$, which is $40 \%$ of the fuel cell's rated continuous output.

\section{Electrical Efficiency}

The fuel cell consumed 1992 gallons of propane to produce 10,490 kWh of electricity. The table below shows the values that were used to calculate the overall electric efficiency of the fuel cell.

\begin{tabular}{|l|l|}
\hline \multicolumn{1}{|c|}{ Description of Quantity } & \multicolumn{1}{c|}{ Value } \\
\hline Cubic ft propane / gal propane & 36 SCF/gal \\
\hline Higher heating value of propane* & 2520.5 BTU/SCF \\
\hline Gallons of propane consumed & 1992 gal \\
\hline kWh electric produced & $10,940 \mathrm{kWh}$ \\
\hline
\end{tabular}

*Higher heating value of propane is a measured value. Measurements were performed by Empact Analytical. Details of the propane analysis are shown on page 28 of this report. 
Using the quantities in the table above, the efficiency for the fuel cell averaged over the 1-year demonstration period was $20.7 \%$.

Thermal Recovery

The ability to extract more energy from the fuel cell adds to the overall efficiency of the demonstration. Due to a problem with the pulse-producing water flow meter in the combined heat and power loop, a flow rate of 4 gallons per minute was assumed for all 1-minute periods during which there was non-zero flow. The CHP supply and return temperatures for each 1-minute period were measured and recorded, allowing energy values to be calculated for each 1-minute period. The table below shows the values that were used to calculate the energy recovered through thermal recovery from the fuel cell.

\begin{tabular}{|l|l|}
\hline \multicolumn{1}{|c|}{ Description of Quantity } & \multicolumn{1}{c|}{ Value } \\
\hline Mix of Glycol and Water in CHP loop & $38.8 \%$ glycol mix \\
\hline Density of glycol/water mix (representative) & $1.06 \mathrm{~g} / \mathrm{cm}^{3}$ \\
\hline $\begin{array}{l}\text { Specific heat of glycol/water mix } \\
\text { (representative) }\end{array}$ & $3.6 \mathrm{Joules} / \mathrm{gram}{ }^{\circ} \mathrm{C}$ \\
\hline Cubic centimeters / gallon & $3785.4 \mathrm{~cm}^{3} / \mathrm{gal}$ \\
\hline kWh per Joule & $2.77 \times 10^{-7} \mathrm{kWh} / \mathrm{Joule}$ \\
\hline
\end{tabular}

Using the quantities in the table above, the total energy recovered through thermal recovery over the 1-year demonstration period was $1736 \mathrm{kWh}$. With the addition of the energy recovered from thermal recovery, the total fuel cell efficiency (electric plus heat) was $23.9 \%$.

\section{Durability}

In this analysis the concept of durability is applied to the fuel cell stack itself, whereas the concept of availability was applied to the whole fuel cell as a system. There were two stacks utilized over a 13-month period including the 1-year demonstration period and the 1-month installation and commissioning period. The first stack experienced reduced cell voltage due to sulfur contamination and was replaced after approximately 632.5 hours of stack operation. Note that the 632.5 hours of stack operation includes only those hours that the fuel cell system was in full running mode and ignores those hours during which the fuel cell system was in some phase of its startup sequence.

The second and final stack utilized by the fuel cell logged a total of approximately 6060 hours before its final shutdown on July 5, 2006. Throughout the stack's life, it was producing power at less than half of its rated capacity in an effort to match the average power needs of the host residence. This de-rating of the fuel cell could have contributed to the high durability of the second stack.

Survivability

In this analysis the term survivability is interpreted to mean the fuel cell systems ability to continue to operate and not be damaged by low ambient temperatures. The stack 
itself was never allowed to experience extreme cold because, as a practical matter, it was known that extreme cold had the potential to inflict severe damage on the stack.

The fuel cell operated in the full range of Upstate New York weather conditions without any damage or apparent degradation of performance. The fuel cell operated in a minimum ambient temperature of -10.7 degrees Celsius (12.8 degree Fahrenheit). The temperature gauge that recorded ambient conditions was located in close proximity to a protected corner between the main part of the host residence and its attached garage. The fuel cell was also located in this semi-protected area. Although lower outdoor temperatures were experienced in the vicinity of the residence during the demonstration period, the fuel cell itself did not experience temperatures lower than 12.8 degree Fahrenheit. The picture below shows the semi-protected corner where the fuel cell and temperature gauge were installed.

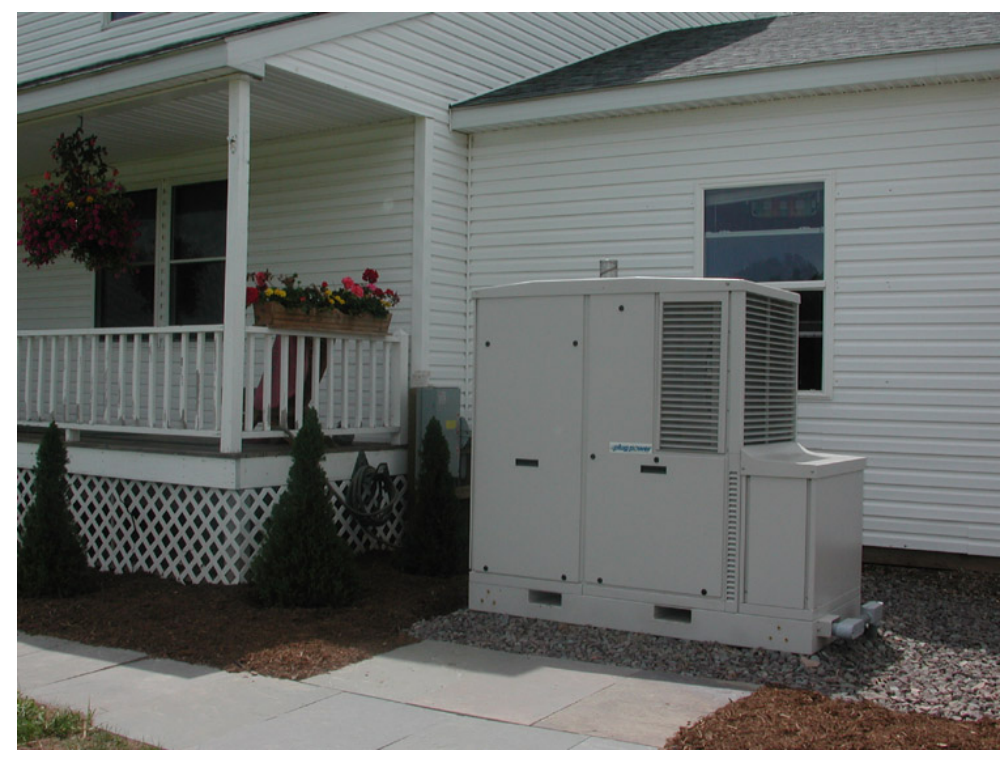

\section{Power Quality}

Power quality data and homeowner feedback from the demonstration project provided valuable insights into the impacts of power quality on the quality of life of residents within a home. From the homeowner perspective, the presence of light flicker was the only noticeable impact of power quality problems during the demonstration. The IEEEdefined quantity called short term flicker is a way of quantifying and comparing the flicker phenomenon in a standard and consistent manner. The figure below shows the unitless short term flicker quantity plotted across a period of time that included straight grid-feed to the energy storage device and the fuel cell feed to the energy storage device. The flicker measurements were recorded at the home's main panel, where it is most indicative of the overall flicker level experienced in the home. 


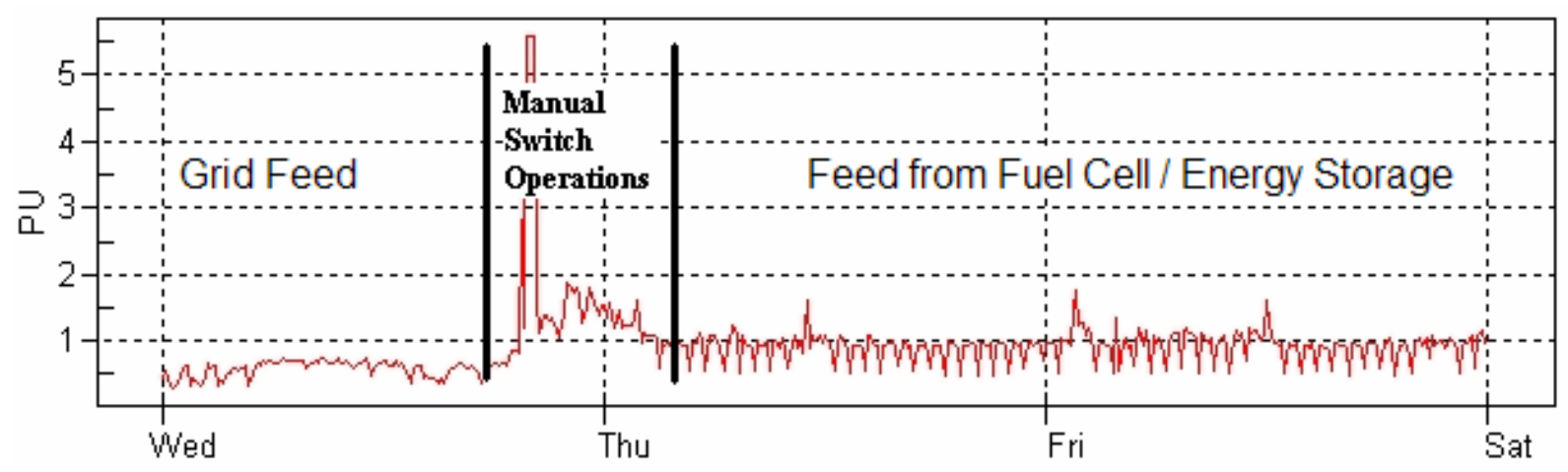

Note that the y-axis label of PU stands for "per unit," which is another way of saying that short term flicker is a unitless quantity. During periods when the utility grid was feeding the energy storage device, the short term flicker values were in the range of 0.5 to 0.8 . During the periods when the fuel cell was feeding the energy storage device, the short term flicker values were in the range of 0.5 to 1.5 with frequent peaks above 1.0 . By definition, a short term flicker value of 1.0 indicates a level of flicker that would be noticeable to $50 \%$ of the human population.

The short term flicker data was corroborated by the experience of the home owner and the project team. During a typical day at the demonstration residence, the home owner met with three other members of the project team. Light flicker was evident or noticeable to the home owner and one project engineer. Two other project engineers could not detect the presence of light flicker. This "subjective" nature of flicker impacts makes this issue even more important to equipment manufacturers, resellers, and installers. Flicker must be assessed and addressed through objectively quantifiable means because each human will experience flicker to a different degree.

The power quality data and home owner experience on this project indicate a need for fuel cells and all distributed generation equipment to be designed and tested for a range of power quality impacts including flicker and total harmonic distortion. It is noteworthy that a fuel cells output power can comply with industry standard power quality curves such as the Computer Business Equipment Manufacturing Association (CBEMA) curve and still present power quality problems to homeowners. For example, the voltage fluctuations that caused the flicker issues for this demonstration were often less than $2 \%$ of the absolute voltage value and lasted lass than $150 \mathrm{~ms}$. These types of fluctuations would not violate the CBEMA curves, but definitely caused flicker that was noticeable to the homeowner.

\section{Noise}

The Plug Power published noise level for their GenSys fuel cell product is $<65 \mathrm{dBA}$ at 1 meter. The experience with noise on this demonstration was anecdotal but it did reinforce the idea that the GenSys noise levels are very low over all modes of operation, startup, and shutdown. Even standing within 15 feet of the fuel cell, it would be impossible to know whether it was running or off based on noise output. The loudest noise produced by the fuel cell, which was infrequent and intermittent, was a radiator fan startup noise. The radiator fan startup noise was audible from tens of feet away 
from the fuel cell, but was not loud enough to be heard from within the residence. Overall, noise was a non-issue for the project team and the homeowner throughout the demonstration.

Emissions

DCEC hired Eastmount Environmental to perform emissions testing on the fuel cell at the demonstration site under typical startup conditions of the demonstration. Eastmount utilized a portable laboratory, which housed gas analysis equipment, calibration equipment and gases, and data recording equipment. Eastmount also did flow rate measurements that, when combined with the composition analysis, could be used to calculate total emissions rates for all the measured stack gas constituents.

The following narrative was produced by Eastmount Environmental and summarizes the emissions test data and methods. Detailed test results and calibration data are available upon request from DCEC. 


\section{$2 \frac{1}{2}$ \\ EASTMOUNT ENVIRONMENTAL SERVICES, LLC \\ Air Quality Specialists}

Mr. Mark Schneider

Delaware County Electric Cooperative, Inc.

P.O. Box 471

39 Elm Street

Delhi, NY 13753

\section{RE: Test Results for Emissions Testing on Tweedie Site Fuel Cell Eastmount Environmental Services Project \#06-086}

\section{Dear Mr. Schneider:}

Please find enclosed the results for the emissions testing that was conducted on the Tweedie Site fuel cell on July 26,2006 . This submittal includes one-minute averages of all parameters measured plus volumetric flow rate calculations, supporting field data, and calibration gas certificates. All data are reported in Appendix A (attached).

The test period occurred from 13:30 to 15:17. In general, $\mathrm{NOx}$ and $\mathrm{SO}_{2}$ emissions were insignificant throughout the operating cycle. However, $\mathrm{CO}$ and total hydrocarbon (THC) emissions were very high during unit startup. As the unit warmed up and stabilized, CO emission diminished from $2500 \mathrm{ppm}$ (off-scale) to approximately $10 \mathrm{ppm}$ over a period of 50 minutes. However THC emissions, which began at 30,000 ppm (off-scale) at start-up, never dropped below 500 ppm during the test period.

The exhaust gas flow rate was measured at 73 wet standard cubic feet per minute or 70 dry standard cubic feet per minute. This data was used to calculate pound per hour emissions. Pound per hour emissions of $\mathrm{CO}$ and $\mathrm{THC}$ are included on the emissions summary sheets at the front of Appendix A.

Eastmount utilized the test methods listed in Table 1 on the following page for the corresponding test parameters.

Seaport industrial Park - 65 Parker street - Unit 3 - NeWburyport, ma 01950

TEL: 978.499 .9300 • FAX: 978.499 .9303 • E-MAll: INFO@EASTMOUNT.COM • INTERNET: WWW.EASTMOUNT.COM 
Table 1 - Test Parameters

\begin{tabular}{|l|l|}
\hline Parameter & Test Method \\
\hline Nitrogen Oxides & EPA 7E \\
\hline Sulfur Dioxide & EPA 6C \\
\hline Carbon Monoxide & EPA 10 \\
\hline Total Hydrocarbons & EPA 25A \\
\hline Oxygen / Carbon Dioxide & EPA 3A \\
\hline Volumetric Flow Rate & EPA 2 \\
\hline
\end{tabular}

Eastmount Environmental Services, LLC appreciates the opportunity to support your air quality management and control programs. If you have any questions regarding this submittal or require additional information, please do not hesitate to call me or David Caron at (978) 499-9300. It was a pleasure working with you on this program.

Sincerely,

EASTMOUNT Environmental Services, LLC

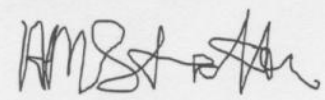

Anthony M. Stratton

Vice President, Technical Services 


\section{Costs and Economic Viability}

This demonstration has considered two factors related to costs and economic viability. The first of these factors is up-front cost and the second of these factors is cost per kWh over the life of the fuel cell.

Up-front Costs

The project costs for this demonstration project were much higher than the costs would have been to install and commission a residential fuel cell without all of the ancillary equipment and personnel costs associated with project planning, data acquisition, monitoring, and reporting. On the other hand, certain equipment was donated to this project that would have been a cost to a "typical" installation. With that in mind, the table below was developed, which summarizes the up-front costs associated with installing and commissioning a "typical" residential fuel cell. No adjustments have been made for changes in equipment or service prices since the unit was installed in 2005. Presumably many costs have gone up while fuel cell costs have decreased, but the table below does not have any speculative information as to how those prices may have changed since 2005.

\begin{tabular}{|l|r|}
\hline \multicolumn{1}{|c|}{ Description of Cost Area } & \multicolumn{1}{c|}{ Amount } \\
\hline Fuel cell equipment purchase and delivery & $\$ 75,700$ \\
\hline Energy storage system equipment purchase & $\$ 14,810$ \\
\hline $\begin{array}{l}\text { Ancillary electrical equipment including transfer switch, split phase } \\
\text { transformer, and new breaker panel and electrical contractor }\end{array}$ & $\$ 4.278$ \\
\hline Thermal recovery equipment purchase and plumbing contractor & $\$ 4,658$ \\
\hline Equipment rental & $\$ 1,244$ \\
\hline $\begin{array}{l}\text { Propane storage, metering, and piping system including 1000 gallon } \\
\text { tank }\end{array}$ & $\$ 3,140$ \\
\hline Ground restoration, seeding, planting & $\$ 499$ \\
\hline Total up-front cost & $\$ 100,055$ \\
\hline
\end{tabular}

The total up-front cost of $\$ 100,055$ purchased and installed a 1000 gallon propane tank, $5 \mathrm{~kW}$ PEM fuel cell, $11 \mathrm{~kW} / 20 \mathrm{kWh}$ energy storage system, and all ancillary equipment and services. Although the electrical energy storage and thermal recovery systems add significantly to the installed cost, the electrical energy storage is arguably necessary for an off-grid application and the thermal recovery is economically beneficial over the life of the fuel cell.

\section{Cost per kWh}

The up-front costs of the fuel cell installation are relatively straight-forward to calculate and do not require any gross assumptions, but the calculation of cost per $\mathrm{kWh}$ requires several assumptions that impact the result. The most conservative calculation approach is to assume that the fuel cell has no useful life after the 1-year demonstration period and calculate a cost per kWh based on the actual costs during that one year. Since the fuel cell was supported by Plug Power's warranty throughout the year, there were no equipment maintenance costs other than DCEC's labor. The following values were used to calculate a cost per $\mathrm{kWh}$ for a fuel cell with a 1-year life: 


\begin{tabular}{|l|r|}
\hline \multicolumn{1}{|c|}{ Description of Assumption } & \multicolumn{1}{c|}{ Value } \\
\hline Total up-front cost including installation & $\$ 100,055$ \\
\hline Maintenance cost for 1 year & $\$ 3,808$ \\
\hline Fuel costs for 1-year (including cost of fuel left in tank) & $\$ 3,614$ \\
\hline kWh produced by the fuel cell & 10,940 \\
\hline
\end{tabular}

Based on the values in the table above, a cost per kWh for the project's fuel cell with a 1 -year life was $\$ 9.82 / \mathrm{kWh}[(\$ 100,055+\$ 3,808+\$ 3,616) / 10,940 \mathrm{kWh}]$.

\section{Enhanced Operations and Maintenance Concepts}

Existing Operations and Maintenance Documentation

For the most part, DCEC was able to follow the recommended and published operations and maintenance procedures and schedules recommended by Plug Power and those procedures and schedules were adequate with few exceptions.

One minor exception was the manner in which thermal recovery was controlled by the fuel cell. The fuel cell has a built-in thermal recovery mechanism that diverts coolant from the radiator to a thermal recovery loop. The thermal recovery function can be enabled or disabled manually through the maintenance interface on a personal computer connected to the fuel cell. However, on the particular GenSys model utilized by this project, the fuel cell did not respond to low temperature conditions in the coolant loop by disabling thermal recovery in an automated fashion. Therefore, the human operator or maintainer of the fuel cell system had to moderate the amount of heat being pulled through the thermal recovery loop by adjusting the heat load within the residence. For example, the space heating thermostat in this demonstration project had to be turned down to avoid excessive heat extraction through the thermal recovery loop. This problem significantly impacted the effectiveness of the thermal recovery system for this demonstration, but the fix to this problem is relatively easy and can be made within the operating software of the fuel cell. It is believed that Plug Power has already addressed this concern for any future releases.

In addition to this minor concern regarding thermal recovery, there was one significant operations and maintenance finding of this demonstration project.

Problem Description

Industry practices in the propane distribution business have not been well understood by fuel cell manufacturers. Established operations and maintenance practices related to the fuel cell reformer's desulfurization bed were found to be incompatible with the established propane industry practice of injecting methanol into new propane fuel storage tanks. The result of the incompatible practices was a failure of the fuel cell stack. DCEC recommends to fuel cell manufacturers that they change their operations and maintenance practices to better handle the presence of alcohol in the propane fuel. Specific Failure Mechanism

It is typical for propane distribution companies to add methanol or another alcohol to new propane tank installations. The purpose of the additive is to combine with water vapor that may be present inside the tank and carry it out of the tank into the fuel load, which in this case is the fuel cell. If water vapor is left trapped in the propane tank, 
corrosion is accelerated and can shorten tank performance and useful life. The alcohol is added to the tank in quantities sufficient to remove most or all of the water vapor.

As fuel is consumed by the fuel cell, alcohol is also boiled out of the propane tank with the propane. As the fuel enters the fuel cell's reformer it passes through a desulfurization bed, which contains small porous beads impregnated with proprietary combinations of catalysts that promote the capture sulfur-containing compounds. The porous beads work on the principal of a combination of chemical and physical absorption onto their large surface areas. The alcohols are preferentially physically absorbed onto the surface of the beads. The alcohols occupy surface area and block access to that same surface by sulfur-containing compounds. As a result, sulfurcontaining compounds are allowed to pass through the desulfurization bed to the remainder of the reformer process and into the fuel cell stack.

Once sulfur-containing compounds reach the fuel cell stack, they can deposit themselves on the proton exchange membrane, thus blocking pathways for the desired process in the stack. Reduced membrane effectiveness leads to lower cell voltages and ultimately to the stack's inability to produce the required power. If the stack fails due to sulfur contamination, the only maintenance option is to remove the affected stack and replace it with a properly functioning stack.

Similar Experience in other Installations

Plug Power personnel were very helpful in diagnosing and repairing the problems caused by alcohol in our propane. Plug was also able to provide data from all their other propane fuel cell installations that had occurred as of November 2005. Twentythree (23) propane-fueled Plug GenSys units had been installed as of November 2005. Twenty-two (22) of those units had experienced sulfur contamination and stack failure within six (6) weeks of commissioning. The one unit that did not experience a similar failure was installed at a location with an existing propane tank (not new), so no alcohol was added to the tank in the weeks or months preceding the fuel cell. Recommended Changes to Operations and Maintenance Practices There are a number of strategies that could be employed to minimize or avoid alcohol's impacts on the performance of the desulfurization bed. Some examples include:

1. Work with the propane provider to minimize the amount of alcohol injected into the propane tank.

2. Plan on changing the desulfurization bed after a very short initial operating period.

3. Add an inexpensive pre-filter based on low cost silica/clay pellets that would provide a large surface area for alcohol physical absorption.

Propane Fuel Testing

DCEC hired Empact Analytical Systems to perform compositional and heat content analysis on the propane gas at two points in the demonstration period. The material below is an example of the test results from a November 7, 2005 sample of the fuel taken just upstream from the inlet on the fuel cell. 
DE-FC36-04G014239

Delaware County Electric Cooperative, Inc.

\begin{tabular}{|c|c|c|c|}
\hline COMPONENTS & $\begin{array}{l}\text { NORM. } \\
\text { MOLE\% }\end{array}$ & $\begin{array}{l}\text { GPM @ } \\
14.696\end{array}$ & $\begin{array}{l}\text { GPM @ } \\
14.73\end{array}$ \\
\hline HELIUM & 0.00 & - & - \\
\hline HYDROGEN & 0.01 & - & - \\
\hline OXYGEN/ARGON & 0.00 & - & - \\
\hline NITROGEN & 0.27 & - & - \\
\hline $\mathrm{CO} 2$ & 0.01 & - & - \\
\hline METHANE & 0.04 & - & - \\
\hline ETHANE & 0.23 & 0.061 & 0.062 \\
\hline \multirow{2}{*}{$\begin{array}{l}\text { PROPANE } \\
\text { ISOBUTANE }\end{array}$} & 97.59 & 26.829 & 26.891 \\
\hline & 0.92 & 0.300 & 0.301 \\
\hline N-BUTANE & 0.92 & 0.289 & 0.290 \\
\hline ISOPENTANE & 0.01 & 0.004 & 0.004 \\
\hline N-PENTANE & 0.00 & 0.000 & 0.000 \\
\hline HEXANES+ & 0.00 & 0.000 & 0.000 \\
\hline 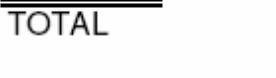 & 100.00 & 27.484 & $\overline{27.547}$ \\
\hline \multicolumn{2}{|c|}{ BTU@ @ 60 DEG F } & 14.696 & 14.73 \\
\hline \multicolumn{2}{|c|}{ LOW NET DRY REAL= } & 2361.2 & 2366.7 \\
\hline \multicolumn{2}{|c|}{ NET SATURATED REAL= } & 2320.1 & 2325.5 \\
\hline \multicolumn{2}{|c|}{ HIGH GROSS DRY REAL $=$} & 2565.2 & 2571.1 \\
\hline \multicolumn{2}{|c|}{ GROSS SATURATED REAL = } & 2520.5 & 2526.4 \\
\hline \multirow{2}{*}{\multicolumn{2}{|c|}{$\begin{array}{l}\text { SPECIFIC GRAVITY ( AIR=1 @14.696 PSIA 60F) : } \\
\text { COMPRESSIBILITY FACTOR : }\end{array}$}} & 1.5551 & \\
\hline & & 0.98250 & \\
\hline
\end{tabular}

NOTE: REFERENCE GPA 2261(ASTM D1945 \& ASME-PTC), 2145, \& 2172 CURRENT PUBLICATIONS

The testing asked of Empact did not include any tests that would indicate the amounts or types of specific compounds that have a tendency to foul the desulfurization bed. If such testing can be conducted economically, it may be advisable have testing done that would help fuel cell operators predict the useful life of a desulfurization bed in the presence of some alcohol. Empact did perform a test to determine the amounts and types of sulfur-containing compounds in the fuel. An example of those results is shown below.

TEST PROCEDURE/ METHOD: SULFUR BY GAS CHROMATOGRAPH SCD 350 *

\begin{tabular}{|c|c|c|}
\hline \multirow[b]{2}{*}{ COMPONENT } & \multicolumn{2}{|c|}{ SULFUR } \\
\hline & $\begin{array}{c}\text { ppm mole } \\
(\mathrm{ul} / \mathrm{L})\end{array}$ & $\begin{array}{c}\text { ppm wt } \\
\text { (ug/g) }\end{array}$ \\
\hline Hydrogen Sulfide (H2S) & 3.9 & 3.0 \\
\hline Carbonyl Sulfide (COS)/Sulfur Dioxide (SO2) & 1.1 & 0.9 \\
\hline
\end{tabular}

Note that undetected sulfur-containing compounds have been omitted from the results above for the sake of clarity. 


\section{Safety Vulnerabilities and Lessons Learned}

DCEC worked with the local code enforcement officer and with our own staff with expertise in the codes published by the National Fire Protection Association to establish the guidelines for safe installation and operation of a propane fuel cell in a residential setting. It was agreed that for this installation we would treat the fuel cell just like one would treat a propane generator. This means that we used the propane connection, setbacks from residences and other structures, and electrical protections that one would normally associate with a propane generator.

DCEC believes that this approach was adequate and did not encounter any additional safety vulnerabilities. Installations of any propane fueled distributed generation would have similar safety risks including combustible gases, hot surfaces, and electrical hazards. There were no occurrences of accidents or near-accidents on the demonstration site throughout the installation, commissioning, or operation of the fuel cell.

In considering potential safety hazards that could be present with fuel cells that one might not be exposed to with generators, only the presence of hydrogen gas comes to mind. The presence of redundant hydrogen sensors within the fuel cell reformer area were a reasonable protection against the build-up of hydrogen gas to explosive levels.

\section{Education of State and Local Consumers}

DCEC and the whole project team worked throughout the 1-year demonstration to use the demonstration as a learning tool for state and local consumers of energy. There were a large number of radio, television, newspaper, and magazine articles that covered the demonstration project and its associated technologies (fuel cells and energy storage). In addition project team members, primarily from DCEC, made a number of presentations on the project and its technologies at local schools, Rotary Clubs, Legion Halls, Town Meetings, and annual meetings of the cooperative members. There were three events in particular that helped to raise the public's awareness of fuel cells and energy storage as relevant technologies to their energy futures:

1. Press event and commissioning celebration in Delhi, NY and Sidney Center, NY on August 11, 2005.

2. Fuel Cell and Energy Storage Educators' Seminar at the State University of New York College of Technology at Delhi on May 9, 2006.

3. Cornell Cooperative Extension clean and renewable energy housing tour in Sidney Center, NY on June 3, 2006.

\section{Press Event and Commissioning Celebration}

DCEC hosted a large press event and fuel cell commissioning celebration on August 11,2005 . The event was well attended by local and regional members of the press as well as local, state, and state-wide elected officials. The keynote speaker at the event was Representative Maurice Hinchey. 


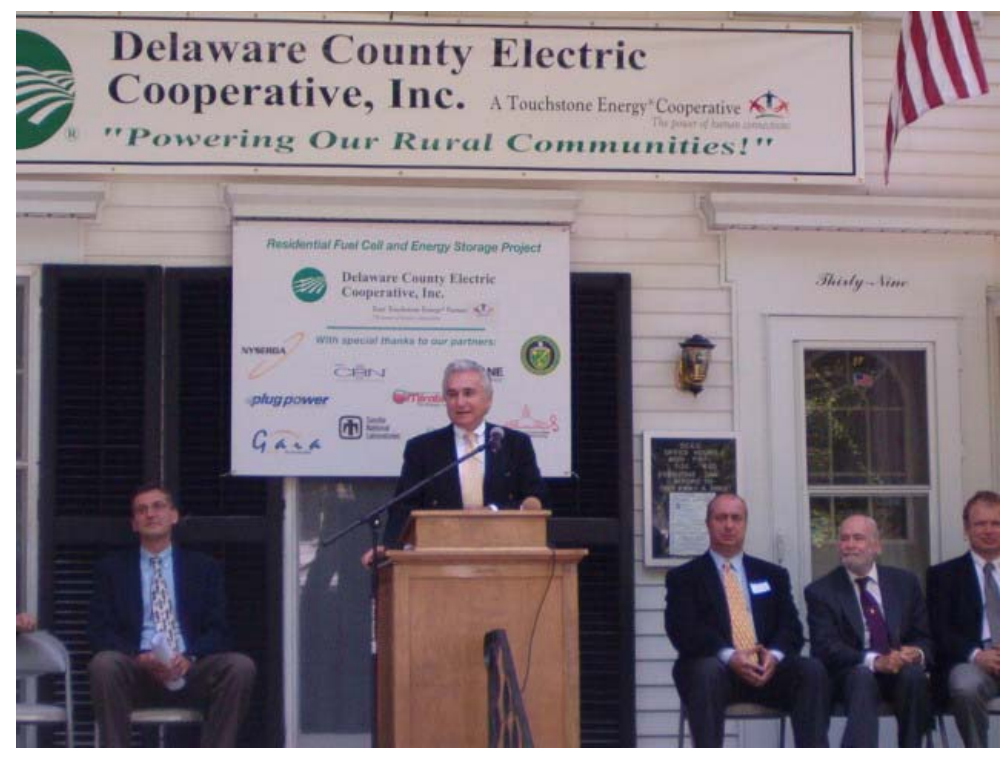

Members of the press and our elected officials were invited to the demonstration site to see the fuel cell and energy storage equipment as they powered the home.

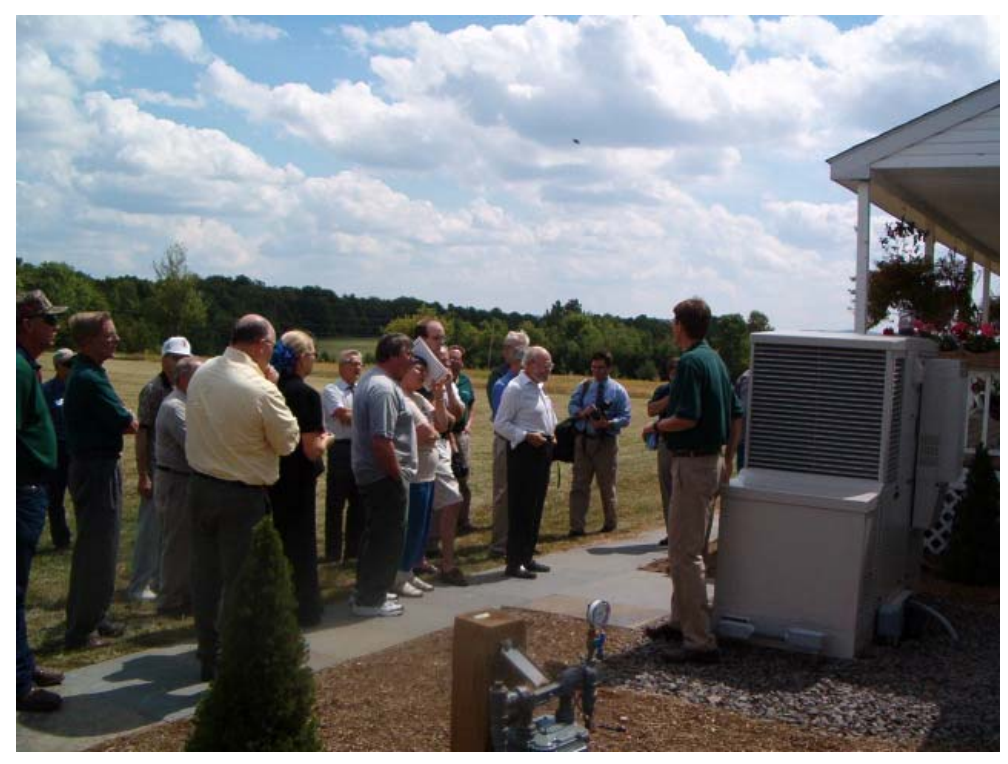

Fuel Cell and Energy Storage Educators' Seminar at SUNY Delhi

DCEC worked with SUNY Delhi and the Community College of Lansing Michigan to codevelop and co-teach a seminar targeted toward secondary and post-secondary educators. The event was well attended by college faculty, high school teachers, vocational educators, and community leaders from the local region and from Lansing, MI. The seminar elevated awareness of fuel cells and energy storage among the attendees and provided some teaching materials, which could then be used by conference attendees when they returned to their own classrooms. The picture below shows one of the faculty members from Lansing, MI giving a presentation on how fuel cells and energy storage fit into the larger context of clean and renewable energy technologies. 


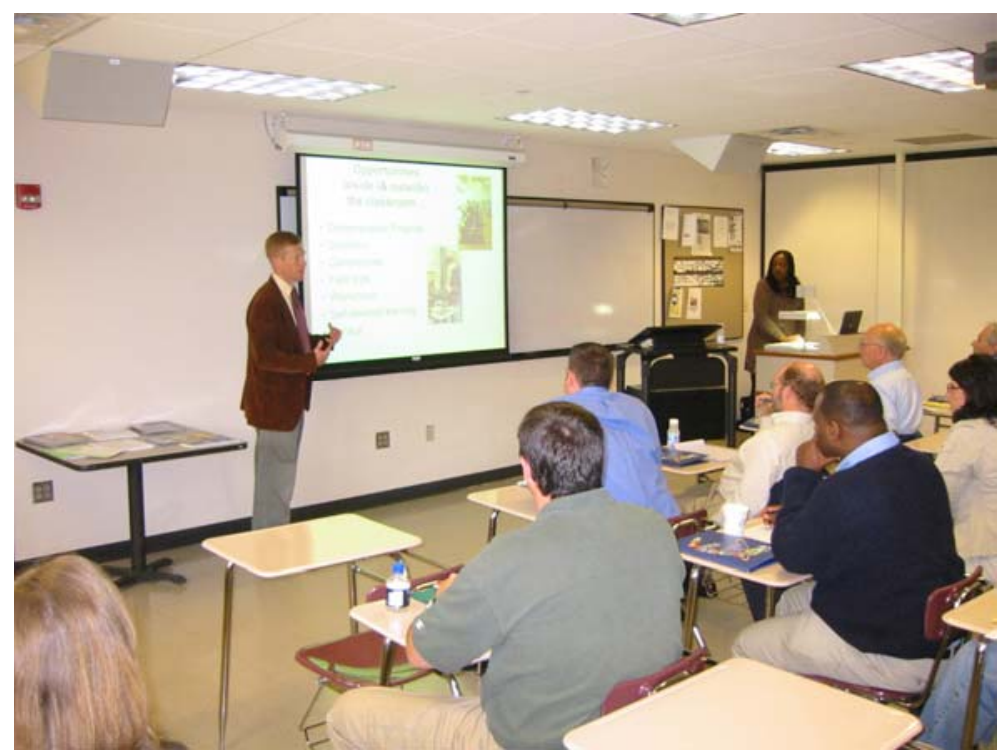

Cornell Cooperative Extension Housing Tour

The Cornell Cooperative Extension Housing Tour was an opportunity for Mark

Schneider, the project manager, to present to approximately 80 people on fuel cells and energy storage, with specific data and lessons learned integrated from the actual demonstration experience. In addition to hearing this presentation, participants made a brief stop at the fuel cell demonstration site to see the fuel cell in action.

\section{Patents}

No patents have been applied for or resulted from this award.

\section{Publications I Presentations}

In addition to the education and outreach events described earlier in this report, the following publications and presentations have been created by project team members and affiliates using data or other relevant information from the demonstration project*:

- Presentation at the Electrical Energy Storage Applications and Technologies conference (EESAT 2005) in San Francisco, CA on October 17, 2005.

- Paper published in the proceedings of the EESAT 2005 conference.

- Presentation at the $19^{\text {th }}$ World LP Gas Forum Global Technology Conference in Chicago, IL on October 18, 2006.

- Presentation at the Energy Storage Association annual meeting in Boston, MA on May 23, 2007.

- Presentation at the EPRI Power Quality Applications (PQA) 2007 and Advanced Distribution Automation (ADA) Joint Conference, Long Beach, CA on June 10, 2007.

${ }^{*}$ This publications and presentation list omits those presentations and publications that resulted directly from the DOE's peer review process and annual meetings. 


\section{Comparison of Accomplishments to Objectives and Goals}

DCEC and its project partners are proud of the fact that we have accomplished each of the project goals that we set for ourselves and those that were set for us by the Department of Energy and our other project sponsors.

This project demonstrated the viability of grid-independent operation of a typical upstate NY home whose total electrical energy needs were met by a propane fueled fuel cell. The demonstration combined intelligently managed energy storage, in-home load control, and combined heat and power to optimize the performance of the fuel cell as a whole-home energy source. The project contributed to enhanced awareness and knowledge among consumers, rural electric cooperatives, fuel cell manufacturers, energy storage manufacturers, educators, and staff members of national agencies and laboratories through a process including public awareness events, publications, educational programs, and technology transfer. The project validated the following objectives of propane fueled hydrogen fuel cells for edge-of-grid residences:

- measured and reported technical performance

- provided raw cost data and economic viability analysis

- documented maintenance and operations concept enhancements specific to residential fuel cells

- shared safety related vulnerabilities analysis and lessons learned

- promoted education of state and local consumers. 


\section{Appendix A - Demonstration Site Log}

The contents of Appendix $A$ are the result of the interpretation and transcription of the site log, which was maintained by DCEC personnel throughout the demonstration period. The site log begins on April 28, 2005 with the first pre-installation work and ends on July 27, 2006 with the removal of the fuel cell. Certain hand-drawn sketches and other details have been omitted from this version of the site log in the interest of efficiency, but those details remain on file in the original site log at DCEC.

Digital photos have been added in certain log entries for the benefit of the reader. These photos are a sampling of the digital photos that remain on file at DCEC.

Throughout the site log, the following individuals are listed by their last names only:

- Randy Brown, plumber, Dubben Brothers Plumbing Service

- Bob Coager, DCEC employee

- Jim Green, DCEC employee

- Erich Gunther, EnerNex Corporation

- Randy Hillis, plumber, Dubben Brothers Plumbing Service

- Jan Morawski, Plug Power Inc.

- Ib Olsen, Gaia Power Technologies

- Nick Pasquale, Gaia Power Technologies

- Mike Pietrantoni, DCEC employee

- Al Reed, DCEC employee

- Ron Schmitz, DCEC employee

- Mike Sackett, DCEC employee

- Mark Schneider, DCEC employee

- Mike Simonds, electrician, Simonds Electric

- Greg Starheim, DCEC General Manager

- Chris Todd, Gaia Power Technologies

- Steve Watkins, DCEC employee

\section{$04 / 28 / 2005$}

Pietrantoni, Schneider, Reed, Sackett, Schmitz

- Installed Signature Systems Dual Node PQ Monitoring device on main panel

- Problem with CT clamp size

- Unloaded fuel cell and placed on cross arms adjacent to planned installation location 

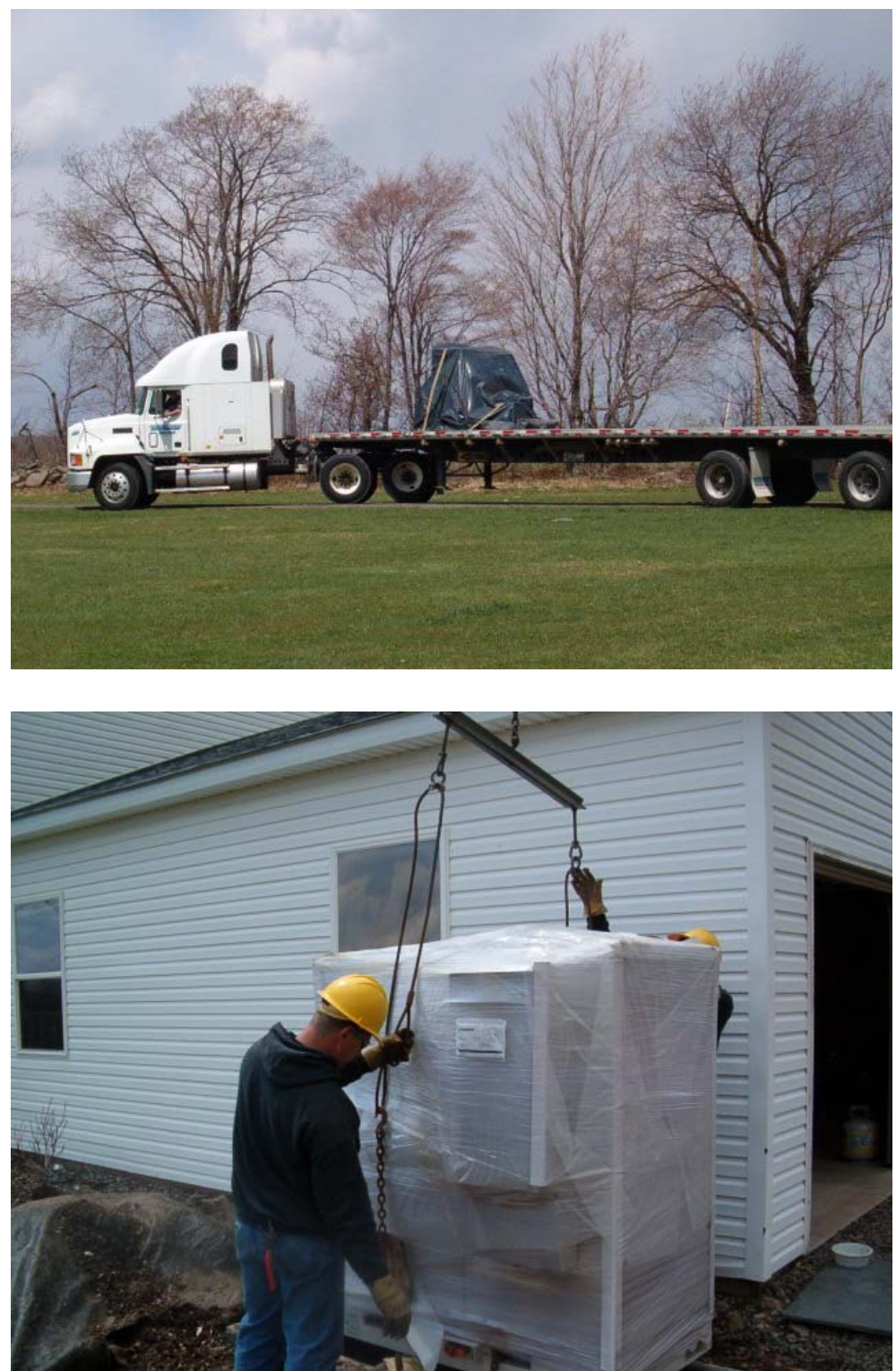

- Reviewed site plan and elevation sketches, making notes

\section{5/02/2005}

Schneider, Chuck Barnes (Culligan Water, Inc.)

- Met Chuck Barnes of Culligan Water on site

- Tested water from the faucet in the basement closest to the entrance from the well

- Hardness $=3$ grains per gallon

- $\mathrm{pH}=6$

- Total Dissolved Solids $=59 \mathrm{mg} / \mathrm{liter}$

- Iron = less than $1 / 2$ ppm

\section{5/05/2005}

Pietrantoni, Schmitz 
- Dropped of loads of sand and stone in front yard adjacent to planned fuel cell installation location

\section{$05 / 09 / 2005$}

Coager, Green, Reed, Pietrantoni

- Dropped of excavator rented from Ackerly and Sons

- Excavated below fuel cell site

- Trenched to house

- Removed water line in way of house penetration in the sill

- Put water valve where filtration unit will be installed

\section{5/10/2005}

Reed, Pietrantoni, Brown, Simonds

- Randy Brown from Dubbens Brothers Plumbing service began running lines between house and fuel cell

- Mike Simonds from Simonds Electric began running conduit between house and fuel cell

- Reed and Pietrantoni began digging propane tank hole, but broke hydraulic line on the back hoe due to old kink in line

\section{5/11/2005}

Reed, Pietrantoni, Brush crew, Mirabito

- Finished excavation for 1000 gallon propane tank

- Set tank with larger excavator from Walton Highway department

- Laid in sand in fuel line trench and around propane tank

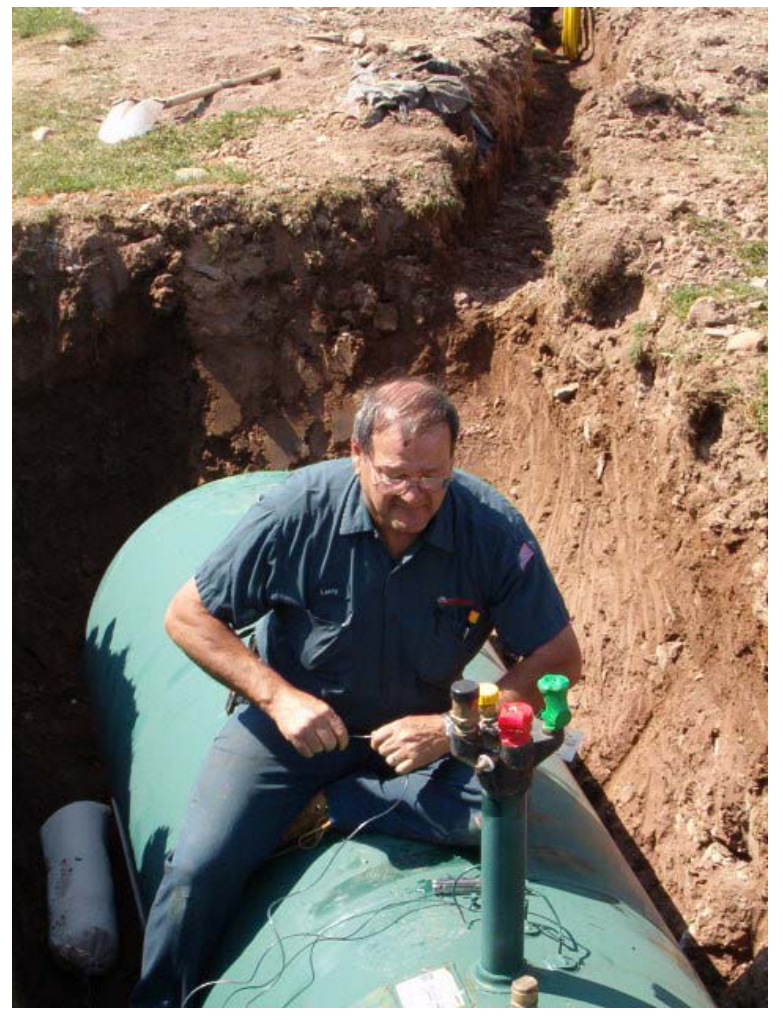


- Got another load of sand so as to have 6" cover over entire tank

- Bill and Mark from Mirabito finished up gas meter connections and left 2 PM

- Set fuel cell 1:30 PM with Tweedie driving skid steerer

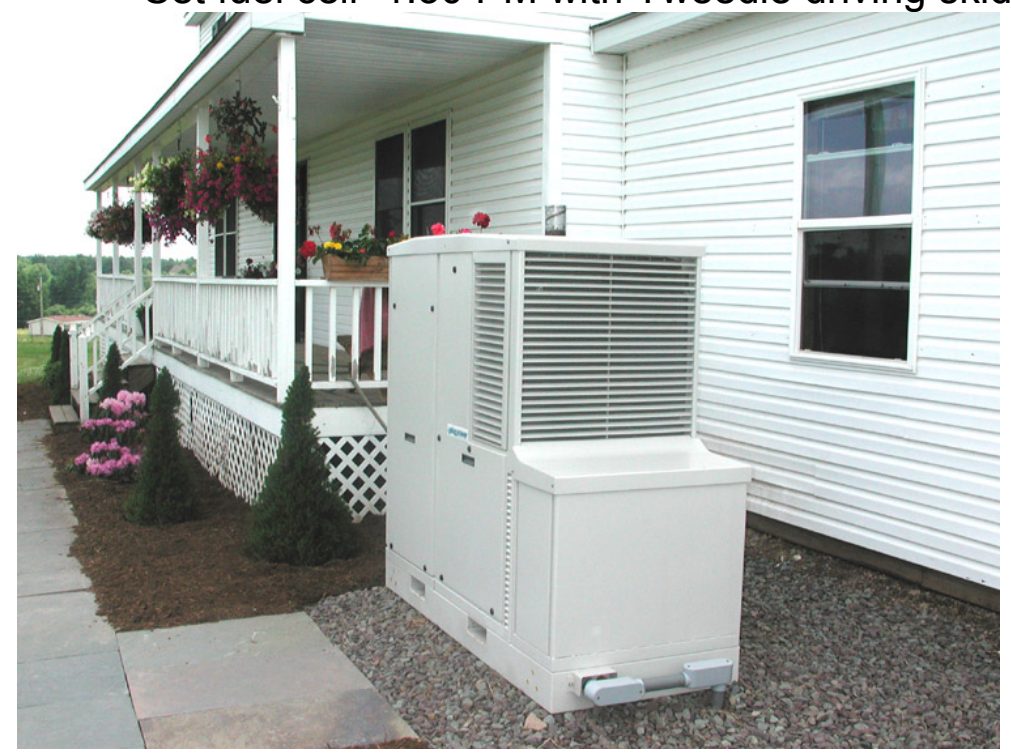

- Don Buel planted flowers

- Johnson and Little planted evergreens around fuel cell, etc.

- Filled in remainder of propane tank hole

- Used truck 51 to move extra dirt out to back of Tweedie property

- Cleaned up rock and left site $\sim 3: 15$ PM

\section{$05 / 12 / 2005$}

Reed, Pietrantoni

- Pietrantoni and Al installed pipe for satellite dish

- Arrived at $\sim 2$ PM and departed $\sim 3$ PM

\section{5/13/2005}

Pietrantoni, Simonds

- Installed plywood on electrical wall in basement

- Installed bi-fold doors to separate project/utility room from finished basement area

- Arrived $\sim 9$ AM and departed $\sim 11$ AM

\section{5/18/2005}

Reed, Pietrantoni, Schneider, Brown, Hillis

- Mirabito hooked up gas line - tested OK 


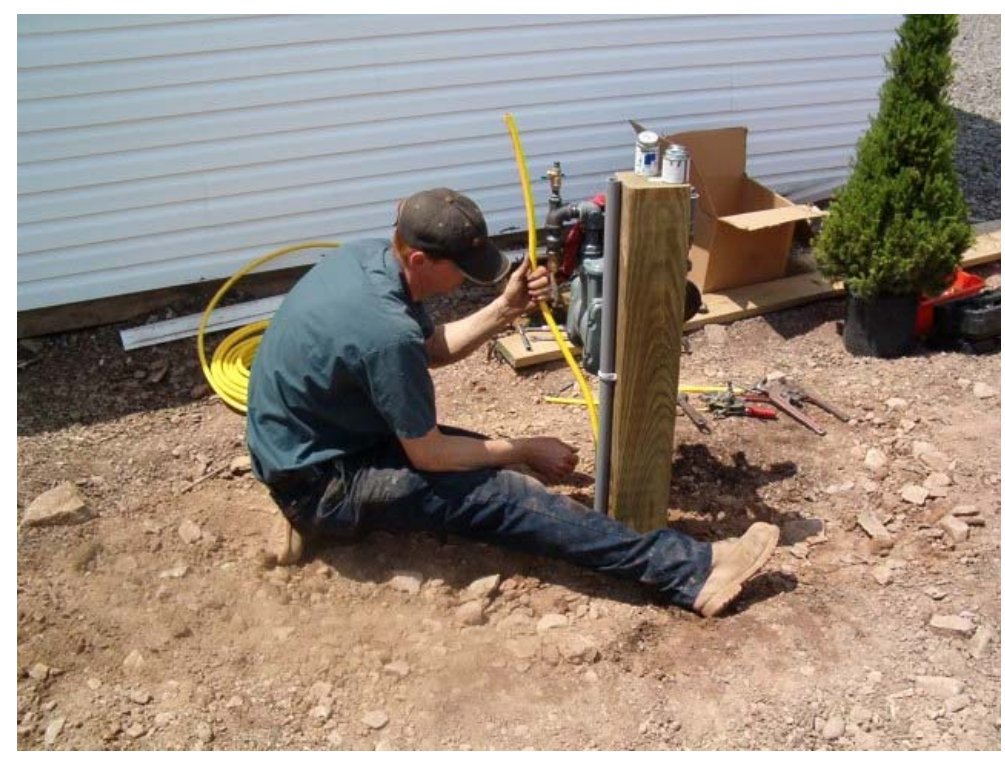

- Dubben Bros. working on plumbing in basement and outside

- Arrived 9 AM and departed 3:30 PM

\section{$05 / 26 / 2005$}

Reed, Pietrantoni, Simonds, Brown, Hillis, Schneider, Satellite Installers

- Satellite dish and modem installed and tested

- Took outage in the afternoon to tie in the automated transfer switch in the basement

- Confirmed with Tweedie that we can install flow meter and thermocouples in the outdoor wood boiler line

- Decided basement thermostat for fuel cell thermal recovery will be on side of basement stairs

- On-site design change - moved relay rack down the wall to between the transfer switch and the Power Tower to facilitate CT and voltage probe connections to the Dranetz BMI data loggers

- Satellite installers suggested looking for between 75 and 80 on signal strength whenever we disconnect and reconnect the satellite modem from the coaxial cable

- Arrived $\sim 9$ AM and departed $\sim 4: 45$ PM

\section{5/27/2005}

Reed, Pietrantoni, Simonds

- Placed cement around below-ground anti-twist horizontal member for added stability

- Simonds continued electrical connections

- Re-tuned satellite dish following cement work

- Arrived 9:30 AM and departed 3:00 PM

\section{$05 / 31 / 2005$}

Pietrantoni, Simonds 
- Made final fuel cell AC connections

- Arrived 9:00 AM and departed 1:30 PM

\section{$06 / 01 / 2005$}

Reed, Pietrantoni, Schneider, Brown, Hillis

- Made final connections for de-ionized water and drains

- Installed fuel cell stack and therminol coolant

- Changed plans and moved DI drain into septic collection instead of simple floor drain due to difficulty in reaching floor drain without inconveniencing home owner

- Brown and Hillis fixed problem with Tweedie well to achieve 40 psi for DI water panel

- Arrived 9:30 AM and departed 3:15 PM

\section{$06 / 02 / 2005$}

Reed, Pietrantoni, Schneider, Morawski, Gunther, Bill from Mirabito

- Opened up fuel cell and prepared for Plug Power arrival

- When Plug arrived, began establishing communications between the fuel cell main board (SARC) and laptop computer with serial cable

- Determined that when using the HP laptop, must bring docking station to avoid the need for cable adapter, which causes problem for communicating with the SARC

- Mirabito performed leak test on full propane line from tank to fuel cell and found no leaks

- Mike Simonds worked on communications connections

- Had communications problems between the SARC and the inverter controller, so Morawski reseated cables and boards and problems seemed to go away, cause unknown

- Checked DI water panel with Morawski's flow meters and achieved a 7:1 flow ratio between waste water and de-ionized water flow to fuel cell

- Morawski helped check for and remove all bubbles from the therminol and glycol systems

- Schneider took propane samples in tedlar bag and cylinder containers, ambient temperature $\sim 70 \mathrm{~F}$ with low to moderate humidity

- Morawski showed Reed and Pietrantoni how to use Tools/Control Algorithm/humidity control to fill water and have the solenoid automatically stop water fill - controlled by the fuel cell, want check box checked to avoid over-filling

- Put the fuel cell in start-up mode

- Erich from EnerNex arrived 12:10 PM to confer with Schneider and Simonds about remaining control and data acquisition wiring connections

- $212: 30$ PM DI water is OK in humidifier and DI tank

- For data acquisition, $1^{\text {st }}$ device power. Then CT's and voltage probes both in transfer switch downstream toward main panel

- Discussed $12 \mathrm{~V}$ power supply for ADAM module - Erich says OK - can run on $<9 \mathrm{~V}$ if necessary 
- Unpacked all analog data acquisition modules (ADAM modules) and seated them in their backplane

- Determined the need for $\sim 100$ feet of thermocouple extension cable and a 6 foot serial cable to complete the ADAM 5000 installation for analog inputs

- Discussed wire types for data acquisition

o Shielded 4-wire OK for pulse meters

o Questions 4-wire shielded for thermocouples and needs to check with BMI engineers

o CAT5 OK for all else

- Discovered that SkyCasters satellite internet provider has changed IP address space from original scheme to the following:

o $\quad 67.45 .172 .10$ thru .14 for inside addresses

o $\quad 67.45 .172 .9$ for modem

o $\quad 255.255 .255 .248$ for mask

- 1:45 PM fuel cell entered full running mode for the first time

- 2:30 PM fuel cell had 36.29 A current output

- Morawski

- Erich completed IP configuration and confirmed EnerNex office connectivity to all data loggers on site

- Erich downloaded ADAM software and installed it

- Morawski suggested we should acquire a small space heater for E-stop conditions. - one that will fit inside the fuel cell.

- Morawski suggested we confirm that the water lines are heat taped from the basement to the fuel cell

- Fuel cell amp output is very unstable - Morawski speculates that the instability is caused by alcohol in the propane.

- $\quad$ 3:00 PM put the fuel cell in slow shutdown mode and achieved full shutdown $\sim 3: 10$ PM

\section{$06 / 03 / 2005$}

Gunther, Schneider, Simonds

- Arrived 7:00 AM

- Erich performed most data acquisition configuration work from hotel over night

- Had trouble getting Info Node to talk to ADAM 5000 over serial port

- Mike Simonds arrived 8:00 AM

- Simonds ran Cat5 cables to remaining sensor points

- Simonds, Mark, and Erich finalized termination positions in the ADAM 5000 module

5017 Card

Chan0

Chan1

5080 Card

Chan 0
Outside Temperature

Outside Humidity

LPG Flow 
Chan 1

Chan 2

Chan 3

5018 Card

Chan 0

Chan 1

Chan 2

Chan 3
CHP Loop Flow

Outdoor Boiler Flow

Oil Burner Timer (left empty at this time)

Thermocouple, CHP From Fuel Cell \#20

Thermocouple, CHP Return to Fuel Cell \#2

Thermocouple, From Outdoor Boiler \#22

Thermocouple, Return to Outdoor Boiler \#21

- Tested thermocouple input $\mathrm{V} 0+, \mathrm{V} 0$ -

o Erich to confirm Red/Blue on +/-

o 5018 module working

o Erich to confirm how to specify range for thermocouples

- Tested pulse counting meter

0 removed pressure valve from propane line to create a large flow

o 5080 module working

- Could not test outdoor temp/humidity sensor because it is on back order

- Summary of issues for Erich

o RS232/485 from Info Node to ADAM 5000

o Thermocouple connection polarity and range specification

- As of $10 \mathrm{AM}$, we resumed PQ monitoring and ended the gap in data collection

\section{6/10/2005}

Schneider, Simonds, Grinaldi, Olsen, Pasquale

- Schneider and Simonds arrived 8:30 AM

- Grinaldi, Olsen, and Pasquale from Gaia arrived $~ 11$ AM

- Pulled all power tower equipment from the truck and moved to basement

- Discovered power tower racks needed more than 5 feet as anticipated

- Decided to move ADAM 5000 module up the wall slightly to allow power tower underneath is

- Relay rack will sit in front of automated transfer switch

- Checked computer communications

o IP address assigned 67.45.172.11

o Default gateway 67.45.172.9

o Info Node .14

o Data Node .13

- Completed battery connections and all power tower connections

- Started battery charge toward full charge state

- Gaia Power left site 4:15 PM

- Spoke to Burl McEndree at 303-637-0150 regarding propane testing

- Pulled a propane tube sample to test for mercaptan

- Devised an ambient pressure propane test sample collection system using an empty and clean water bottle with the normal twist-off cap hole on one end and 2 additional smaller holes cut in the other end 
o Propane enters the bottle through the normal twist-off cap hole in the top of the plastic bottle

o One of the two new holes is used to insert a sampling tube

o The second of the two new holes remains open, which allows propane to flow out of the bottle such that ambient pressure is maintained

- Test results of mercaptan test

o saw dark orange line $\sim 2 \mathrm{ppm}$

o gray line well beyond $120 \mathrm{ppm}$

0 after re-reading directions, believe that gray line is unrelated to mercaptan

0 will send test tube for review by Empact Analytical

- Mark left site $\sim 5: 15$ PM

\section{$06 / 14 / 2005$}

Pasquale, Schneider

- Arrived on site $\sim 10: 45$ AM

- Nick added current transformers (CTs) to the transfer switch running back to power tower so power tower will know when to cut itself back in the event of overload conditions

- Mark unable to perform propane testing because he doesn't have the required tedlar bag

- Spoke to Empact Analytical and they will overnight tedlar bag

- Worked by e-mail with Erich of EnerNex from 1 PM to 5 PM

o Router/firewall (encore) from Skycasters came mis-configured

o Could not resolve configuration issues

o Sent config file to EnerNex and Skycasters for their review

- Nick and Mark left site 5:15 PM

\section{$06 / 16 / 2006$}

Pietrantoni, Schneider, Simonds, Reed

- Mark and Mikes arrived 8:45 AM

- Started fuel cell to test battery storage system

- Mark took propane samples $\sim 9$ AM

- Reed arrived 9:30 AM

- After starting fuel cell got an E-stop with error codes as follows

o 1.929, FS7 Press.2 FS9 14.3.13

o 2.524, Air Comm 14.3.1.7

o 3.525, Fuel Comm

o 4.546, ATO loss 14.3 .10

- We opened electronics enclosure as per error code instruction to watch LEDs and hit started fuel cell again

- Hit start button twice to by-pass the 8 minute enclosure air purge

- Fuel cell went into manual mode and on into startup mode

- Nick from Gaia arrived 10:45 AM 
- Mike Simonds switched the grid and the power tower inputs in the transfer switch such that the Power Tower became the primary input to the transfer switch and the grid became the secondary input to the transfer switch

- Now when you look at the transfer switch front panel, the LED's indicate the following conditions:

o LED next to utility pole symbol lit - means that Power Tower is available

o LED next to generator symbol lit - means that grid is available

o LED below the utility pole symbol lit - means that the Power Tower is currently feeding the main panel

o LED below the generator symbol lit - means that the grid is currently feeding the main panel

- Noted that the symbols on the front panel of the transfer switch are now counterintuitive

- This configuration allows the transfer switch to see the combination of the fuel cell and energy storage (Power Tower) as the primary input

- Nick connected a second LinkSys BEFSR41 router as 67.45.172.13 and tested communication through this new router (to be called the Gaia router) to his laptop. Communications worked fine from laptop to Internet.

- From Nick's laptop on the Gaia router

o Ping 67.45.172.9 - timeout

o Ping 67.45.172.10 - reply Encore

o Ping 67.45.172.11 - timeout

o Ping 67.45.172.12 - reply Data Node

o Ping 67.45.172.13 - reply new Gaia router

o Ping 67.45.172.14 - timeout

- Reset Gaia router to static IP address 67.45.172.11

- From Nick's PC on Gaia router, logged into www.direcwaysupport.com

- Confirmed modem address 67.45.172.9

- Repeated ping tests

o Ping 67.45.172.9 - reply from modem

o Ping 67.45.172.10 - reply Encore

o Ping 67.45.172.11 - reply Gaia router

o Ping 67.45.172.12 - reply Data Node

o Ping 67.45.172.13 - reply Dual Node Info Node

o Ping 67.45.172.14 - reply Dual Node Data Node

- Called Darren at EnerNex 865-691-5540 x120

- Darren pinged entire IP range

o Got responses except for Encore (.10)

- Network test PC setup

o IP - 10.0.105.16

o Submask - 255.255.255.0

o Default router - 10.0.105.1

- $\quad$ 3:01 PM closed cutout between fuel cell and Power Tower - no problems

- $\sim$ 4:12 PM manually moved transfer switch position such that house load fed from Power Tower - no problems 
- $\quad$ 4:40 PM flipped main breaker upstream of feed to fuel cell to off position such that fuel cell could no longer see grid voltage - fuel cell transitioned from grid parallel mode to standby mode and continued feeding Power Tower.

0 Voltage on grid connection to fuel cell $0.2 \mathrm{~V}$

o Voltage on grid connection to Power Tower $<1.7 \mathrm{~V}$

- $\quad$ 4:46 PM manually switched back main panel to grid

- Anomaly observed - Gaia inverter controller reset itself with each grid power switching event - don't understand this behavior

- Summary of Gaia Power Tower test modes

o Fuel cell charging batteries: OK

o Fuel cell limited to $9 \mathrm{Amps} / \mathrm{ph}$ ase: OK

- Fuel cell feeding Power Tower, feeding loads including hot tub to a max of 31-32 Amps/phase: OK

- Fuel cell feeding Power Tower, feeding loads including hot tub to a max of 31-32 Amps/phase while fuel cell limited to 9 Amps/phase: OK

o Grid drop out: OK

- Fuel cell drop out: OK

- 4:51 initiated slow/long shutdown on fuel cell

- $\sim 4 ; 54$ error code $(512)(0)$ on fuel cell

- 5:04 PM noticed fuel cell restarting itself, pushed shutdown button

- Could not test load control circuits today due to bad transformer for relay circuits so Mike Simonds will bring replacement

- 5:15 PM left site (Simonds, Schneider, Pasquale)

\section{$06 / 21 / 2005$}

Schneider, Simonds, Reed, Pietrantoni, Brown

- 8:30 AM Schneider arrives on site and Simonds waiting for him there

- Simonds replaced transformer for load control

- One relay works but the other does not

- 9:06 AM powered up fuel cell with single press of start button (did not by-pass enclosure air purge)

- 9:14 AM, communications came up right away

- Note that we are trying communications to my laptop with laptop's base station instead of USB to serial converter cable - direct DB-9 connection - still see frequent communications errors with fuel cell

- DI water fill indicator reads $118 \%$ upon startup - bad sensor?

- 9:30 AM Randy Brown arrived and put thermocouples into thermal exchange loops

- 9:49 AM humidifier reached water level of 2.8 and dropped down again

- $\quad$ 10:25 AM Randy Brown pressure tested CHP loop and found leak in the manual bleed valve within the fuel cell

- 12:25 fuel cell went into Running/Running/Running

- called Vinny at Plug Power to find out when CHP loop is enabled

- Vinny stated after Running/Running/Running

- CHP loop held exactly 9 gallons 
o $\quad 38.8 \%$ glycol mixture

- 5 gallons glycol at $70 \%$

- 4 gallons distilled water

- When fuel cell went into full running state, CHP loop started at $\sim 130$ degrees, then settled in at $\sim 100$ degrees

- Reed adjusted DCEC distribution system voltage down by 2 Volts to avoid distributed generation assets like the fuel cell seeing over-voltage on their grid inputs

- Communications still went bad occasionally for a few seconds every once in a while, even with straight serial connection between the laptop and the fuel cell

- Exercised transfer switch a couple times and fuel cell handled very well, Power Tower also handled very well

- Randy Brown departed 1:30 PM

- 2:39 PM fuel cell showed low cell alert and then shut itself down with error codes:

o 500 (low cell trip alert)

o 503 (fuel cell contactor retry timing out)

- Troubleshooting ModBus connection from EnerNex Widget to fuel cell

\begin{tabular}{|l|l|l|l|}
\hline RS422 & $\begin{array}{l}\text { RJ45 on Fuel Cell } \\
\text { SARC }\end{array}$ & Outside Colors & Cat5 Inside Colors \\
\hline Y & TX+ & Blue & Blue \\
\hline Z & TX- & Black & Blue White \\
\hline B & RX- & Red & Green \\
\hline A & RX+ & Green & Brown White \\
\hline
\end{tabular}

- Pietrantoni, Reed, and Erich left @ 5:20 PM

\section{$06 / 24 / 2005$}

Schneider

- IP configurations

o 10.0.105.12 Data Node user: admin, password: password

o 10.0.105.13 Data Node user: admin, password: password

o 10.0.105.14 Info Node user: admin, password: password

- RJ45 terminations on white Cat5 cables

o Tab up, blank, blank, blue on white, blue, blank, blank

- RJ11 terminations

o Black, red, green, yellow

\section{$06 / 28 / 2005$}

8:30 PM call from Tweedie to Schneider

- Tweedie having trouble with electric in house

- Running air conditioner, hot tub, and vacuum simultaneously 
- Schneider instructed Tweedie to turn off output breakers on Power Tower while on the phone - resulted in transfer switch sensing lack of voltage from Power Tower and switching input from Power Tower to grid

- Schneider arrived on site $\sim 9$ PM

- Wedged a tool in the load management contact closure to hold down manual close button

- Schneider left site 9:30 PM

\section{$06 / 29 / 2005$}

Schneider

- Checked for reason for Internet being down

- 15 Amp breaker in main panel was flipped off

- Flipped 15 Amp breaker back on in main panel

- Sent e-mail notification to Gaia and EnerNex and both confirmed that connectivity had been restored

- Confirmed modem settings on fuel cell

- Still no response from fuel cell modem

- Called Plug Power at 518-782-4000 and talked to Dave

- Dave had some additional modem tests before deciding to send me a new SARC board

- Recorded the following information from the LPG gas meter nameplate

o Make American Meter Co.

o Model AC-250

o S/N 03D459568

- Called iMAC at 800-955-4GAS and they told me that the meter outputs 10 pulses per revolution

- Still need to confirm the volume of gas per revolution of the AC-250 meter

- Did a manual transfer to grid at 2:35 to avoid any unnecessary problems for Tweedie between now and Friday

- Pulled a stain tube of propane to send to Larry Osgood at the Propane Education and Research Council

- Saved stats file and system ID information from the fuel cell in preparation for the SARC upgrade planned for Friday

- Commanded fuel cell to power down 3:03 PM

- Recorded Amp ratings on communications equipment to be certain that the circuit is not overloaded, resulting in breaker tripping
0 EnerNex Widget .1 A
o Gaia Router .1 A
o EnerNex Router .1A
o VSR-30 VPN $.5 \mathrm{~A}$
o UPS
$12 \mathrm{~A}$
- Gaia Controller
- Ethernet Switch $.5 \mathrm{~A}$
- Modem 1.3 A

o Data Node .2 A 

o Info Node
o Total
$.5 \mathrm{~A}$
$13.5 \mathrm{~A}$

\section{$07 / 01 / 2005$}

Pasquale, Schneider, Reed

- Breaker trip research

o Measured current on input/output of transformer for load control - no spikes

o Inconclusive

- Found loose wire between controller relay and transfer switch - fixed

- Replaced power supply for Gaia controller to see if the resets will stop occurring with transfer switching events

- Added dedicated UPS for Gaia controller to reduce impact of switching events on the Gaia controller

- Removed $\sim 15$ feet from the length of the signal wires between the Gaia controller and the Power Tower

- Installed a manual bypass switch for Tweedie in case of future power problems in the house

o Hardware only solution

o Bypasses relay board on the controller

o Holds transfer switch in exercise position

o Holds 28 volts on the hot tub relay

- Tested manual bypass several times

o During one test we had a possible reboot of the Gaia controller upon transfer action but possibly confounded by having hands in the controller hardware at the time of the test

o Other tests worked fine

- Reed replaced the SARC on the fuel cell

- Powered up the fuel cell into manual mode just fine

- Modem still did not work

- Tried various things on the phone with Plug Power tech support

- Isolated the problem at the connector for the RJ-11 on the Power Distribution Board (PDB)

- Found if I pushed the connector up into the plug just right I got a good connection

- Successfully tested modem in both directions (call-in, call-out)

- Had Morawski from Plug Power set power output settings to $2 \mathrm{KW}, 3 \mathrm{~kW}$ and $4 \mathrm{~kW}$ because these settings were not available locally to me

- Upon completion of configuration by Plug I tried a startup sequence on the fuel cell

- E-stopped due to "lack of fuel"

- Upon E-stop, system called Plug and sent e-mail to me (at least comms are working)

- Per suggestion by Vinny at Plug Power, purged LPG line just before entry into fuel cell

- Ran fuel cell startup sequence again 
- Fuel cell was running at $\sim 5: 40 \mathrm{PM}$

- Nick made a DB-9 connector for the ModBus connection to the EnerNex Widget using the following color scheme;

\begin{tabular}{|l|l|l|}
\hline TxA $(-)$ & Blue/White & Pin 8 \\
\hline TxB $(+)$ & Blue & Pin 3 \\
\hline RcvA $(-)$ & Green & Pin 2 \\
\hline Rcv B(+) & Brown/White & Pin 7 \\
\hline Signal Grounds & Green/White & Pin 6 \\
\hline Signal Grounds & Brown & Pin 4 \\
\hline
\end{tabular}

- Called EnerNex to confirm ModBus connection

o Erich confirmed that Comm1 is active but could not confirm commands because he didn't know the Plug Power commands

- Left EnerNex widget on EnerNex router

- Left stand-alone Data Node on Lan port of VPN through no-hub cable

- Nick left site $\sim 4: 30$ PM

- Mark left site $\sim 4: 50$ PM

\section{7/06/2005}

Schneider

- Arrived $12: 30$ PM

- Moved all local network connections onto VPN connection

- Re-routed all cables and tied them down on communication rack

- Did not do anything with the fuel cell

- Left site 5:30 PM

\section{$\underline{07 / 11 / 2005}$}

Schneider

- When I arrived on site $~ 10: 30$ AM, one of the UPS's was beeping and showing the LED blinking on and off

- I plugged that UPS directly into the outlet just below the main panel and the beeping stopped

- I started the fuel cell and 10:40 AM.

- Fuel cell immediately failed due to inverter communications.

- Restarted the fuel cell 10:50 AM

- I examined why the outdoor temp/humidity sensor is not working

o Did not see any wiring problem

- Contacted Jack at EnerNex by e-mail

o Per Jack King, missing $125 \mathrm{Ohm}, 1 \%$ resistors across input terminals

- Looked at ModBus connection problem

o http://10.0.105.20/test-cgi/modbus-cgi.cgi?startreg=240\&numregs $=2$

\section{$\underline{07 / 14 / 2005}$}

Pietrantoni, Reed, Schneider

- arrived on site $~ 8: 45 \mathrm{AM}$ 
- Installed new inverter on fuel cell

- Very hot/humid conditions

- Completed inverter change-out 10:45 AM

- Noted that the new inverter is different model than the one we removed

- Started fuel cell into manual mode and saw immediately that we had bad inverter communications

- Wiggled the wires to RJ11 in inverter breaker panel

- Restarted after complete power down and the error was gone

- Saw low battery warning - realized that 2 breakers were off, so we corrected the problem and error went away

\section{$07 / 14 / 2005$}

Schneider

- Documented as-built

- Documented data logging equipment connections

\begin{tabular}{|c|c|}
\hline \multicolumn{2}{|l|}{ Data Node } \\
\hline $\mathrm{V}_{\mathrm{A}}$ & L1 from Fuel Cell to Power Tower \\
\hline $\mathrm{V}_{\mathrm{B}}$ & L2 from Fuel Cell to Power Tower \\
\hline $\mathrm{V}_{\mathrm{c}}$ & Jumper L2 from Fuel Cell \\
\hline $\mathrm{V}_{\mathrm{N}}$ & Not Used \\
\hline$I_{A}$ & $\begin{array}{l}\text { L1 input to Power Tower } \\
\text { (either Fuel Cell or Grid, depending on operating state) }\end{array}$ \\
\hline $\mathrm{I}_{\mathrm{B}}$ & $\begin{array}{l}\text { L2 input to Power Tower } \\
\text { (either Fuel Cell or Grid, depending on operating state) }\end{array}$ \\
\hline Eth & Ethernet connection to Ethernet switch \\
\hline \multicolumn{2}{|l|}{ Dual Node } \\
\hline $\mathrm{V}_{\mathrm{A}}$ & $\begin{array}{l}\text { L1 input to House Main Panel } \\
\text { (also known as the output from the Transfer Switch, } \\
\text { which can be fed by the Grid or the Power Tower } \\
\text { depending on operating state) }\end{array}$ \\
\hline $\mathrm{V}_{\mathrm{B}}$ & $\begin{array}{l}\text { L2 input to House Main Panel } \\
\text { (also known as the output from the Transfer Switch, } \\
\text { which can be fed by the Grid or the Power Tower } \\
\text { depending on operating state) }\end{array}$ \\
\hline $\mathrm{V}_{\mathrm{c}}$ & Jumper L2 \\
\hline $\mathrm{I}_{\mathrm{A}}$ & L1 input to House Main Panel \\
\hline $\mathrm{I}_{\mathrm{B}}$ & L2 input to House Main Panel \\
\hline Comm1 & To ADAM Module \\
\hline Eth & Ethernet to Ethernet Switch \\
\hline \multicolumn{2}{|l|}{ ADAM Module } \\
\hline 5017 Input Card V 0 & Outdoor Temperature \\
\hline 5017 Input Card V 1 & Outdoor Humidity \\
\hline 5080 Input Card COA & LP Gas Pulse Counter Flow Meter \\
\hline 5080 Input Card C1A & $\begin{array}{l}\text { Combined Heat and Power Loop Pulse Counter Flow } \\
\text { Meter }\end{array}$ \\
\hline
\end{tabular}




\begin{tabular}{|l|l|}
\hline 5080 Input Card C2A & Outdoor Boiler Pulse Counter Flow Meter \\
\hline 5080 Input Card C3A & Reserved for Future Use (Oil Burner Pulse Counter) \\
\hline 5018 Input Card 0 & $\begin{array}{l}\text { Thermocouple Temperature in CHP Loop from Fuel } \\
\text { Cell }\end{array}$ \\
\hline 5018 Input Card 1 & $\begin{array}{l}\text { Thermocouple Temperature in CHP Loop return to } \\
\text { Fuel Cell }\end{array}$ \\
\hline 5018 Input Card 2 & $\begin{array}{l}\text { Thermocouple Temperature in Loop from Outdoor } \\
\text { Boiler }\end{array}$ \\
\hline 5018 Input Card 3 & $\begin{array}{l}\text { Thermocouple Temperature in Loop return to Outdoor } \\
\text { Boiler }\end{array}$ \\
\hline RS232 & Connected to Duel Node port Comm1 \\
\hline
\end{tabular}

- Documented network connections

- An as-build sketch from 07/11/2005 is omitted from this Appendix, although the sketch is found in the original site log on file at DCEC

- Left site 2:20 PM while fuel cell was still approaching full running state

- Left site in configuration to push all power generated by the fuel cell back on the DCEC distribution grid

\section{$07 / 19 / 2005$}

Schneider, Pietrantoni, Reed

- Investigated reason for shutdown status of fuel cell

- Downloaded all log files and sent to Plug Power

- Pietrantoni re-wired mod-bus connection as follows

\begin{tabular}{|l|l|l|}
\hline TX+ & Blue & Pin 3 \\
\hline TX- & Blue/White & Pin 8 \\
\hline RX- & Green & Pin 2 \\
\hline RX+ & Brown/White & Pin 7 \\
\hline Gnd & Green/White & Pins 4\&6 \\
\hline V+5 & Brown & Hooked to nothing \\
\hline
\end{tabular}

- Pietrantoni determined that a smaller solder gun is required

- Reed put $125 \Omega$ resistors on ADAM 5017 module inputs 0 and 1 and shorted the remainder

- Left site $\sim 11: 05 \mathrm{AM}$

\section{$07 / 26 / 2005$}

Pietrantoni, Reed, Schneider

- Arrived on site 9:30 AM

- Called Rob at Plug Power and got instructions as to how to proceed

- Power up Fuel Cell to manual mode

- Error message appeared as follows: Abort_DATA_Transfer Error Code 131

- Spoke to Dave at Plug Power tech support. Dave instructed us to check modem enabled, power down unit and restart to the manual mode. Once in the manual mode, unplug the computer from the fuel cell so that he can call into the fuel cell. 
- Rob Lowen from Plug Power called and asked us to power down, remove plug $B$ $\left(2^{\text {nd }}\right.$ from the left) from the SARC for 10 to 15 seconds, then re-plug plug B into the SARC.

- Left fuel cell in a mode where Plug Power could work on it remotely over the modem connection.

- Pietrantoni re-wired mod-bus connection, eliminating the $V+5$ connection. No luck with this or other pin-outs.

- Left site $\sim 12: 30$ PM

\section{$07 / 19 / 2005$}

Schneider

- Arrived on site 7:30 AM

- Fuel cell LED indicator was lit and the fuel cell was throwing some heat.

- Plugged computer into the fuel cell local port and started the service software.

- Fuel cell was in full running mode (running/running/running) and there was an $\mathrm{H}_{2}$ stoich alert.

- $\quad$ 7:53 AM DC measured voltage at BT3 POS Sensor in battery compartment $24.9 \mathrm{~V}$ to grand and - terminal.

- $\sim 7: 57$ measured load to neutral AC voltage of $126.3 \mathrm{~V}$

- $~ 8: 00$ measured DC voltage out of stack in the range of 65.4 to $67.4 \mathrm{~V}$ with a steady voltage of $66.8 \mathrm{~V} \mathrm{DC}$ after about 2 minutes of monitoring

\section{7/29/2005}

Schneider, Starheim (DCEC), Indera, Dave (Plug Power), Tweedie and son Alex (home owners)

- Arrived 10:30 PM

- Took pictures of equipment and home owners, inside and outside the home

- Left site $\sim 12: 15$ PM

\section{$08 / 01 / 2005$}

Schneider, Pietrantoni, Reed

- Arrived $\sim 10 \mathrm{AM}$

- Removed old fuel cell stack and installed new stack

- Started fuel cell 1:50 PM

- Left system in a state that Plug could call into it

- Left site $\sim 2: 30$ PM

\section{$\underline{08 / 03 / 2005}$}

Schneider

- Arrived 6:30 AM

- Fuel cell power up but not running 
- Connected PC to local port on fuel cell, started service software

- Issued startup command to fuel cell 6:42 AM

- Left site $\sim 6: 55$ AM

\section{8/03/2005}

Pietrantoni, Reed, Morawski (Plug Power)

- Morawski started the fuel cell to run some tests

- Morawski confirmed that the Inverter had the wrong set points when the new inverter was installed on 07/14/2005.

- Morawski changed out the inverter again with one he had brought with him from Plug and had the correct inverter settings in it.

- Morawski restarted the fuel cell, which went to running/running/running state $\sim 11: 30 \mathrm{AM}$

- Morawski ran some additional tests to confirm that it was the inverter causing our shutdown problems prior to today.

- Morawski, Reed, and Pietrantoni discussed the possibility of a $2.0 \mathrm{~kW}$ fuel cell output setpoint, but did not implement it yet.

- Left site with fuel cell in running/running/running state at $\sim 12: 30 \mathrm{PM}$

\section{$\underline{08 / 10 / 2005}$}

Pietrantoni

- Confirmed that fuel cell is still running/running/running and providing power to the Power Tower

- Confirmed that Transfer Switch is in the "normal mode," meaning that power is flowing through the Transfer Switch from the Power Tower to the House Main Panel.

- Pietrantoni installed plywood and insulation around the conduit entrance to the basement of the house and did some site clean up.

- Left the site $\sim 9: 30 \mathrm{AM}$

\section{$08 / 24 / 2005$}

Schneider, Pietrantoni

- Arrived 1:00 PM

- Came to check fuel cell shutdown

- Upon our arrival, the fuel cell had restarted itself automatically and was in running/running/running mode.

- We contemplated connecting the fuel cell's user interface panel to the fuel cell, but it can not be connected unless the fuel cell is in shut-down state and we did not want to shut the fuel cell down.

- Departed 1:35 PM

\section{$\underline{08 / 30 / 2005}$}


Schneider, Watkins (DCEC), Pasquale (Gaia), Morawski (Plug Power)

- Arrived $\sim 11 \mathrm{AM}$

- $~ 11: 23$ AM, Nick opened the circuit breaker to the Power Tower AC grid input and 3 seconds later the Transfer Switch took an automated action to switch to the grid feed (away from the Power Tower feed)

- The fuel cell shut down due to loss of inverter communications

- Morawski restarted the fuel cell

- Performed tests

o Test 1

- while running the Power Tower from the grid and net metering from the fuel cell, increased power consumption on Power Tower AC2 from grid

- saw that FC no longer needed to push as much power back to grid

- FC inverter voltage able to drop because no longer pushing as much current back to grid

- had 2 burners on stove, a fan, and a bunch of lights on to create pulsating load

o Test 2

- closed cut-out between FC and Power Tower

- at first, FC "passed thru" grid power from grid and provided whatever portion it could provide

- FC ramped up to $4 \mathrm{~kW}$ and stayed there

- Stack voltage improved by $\sim 2$ Volts due to re-hydration

- When FC pushing small amount of power to grid, only small voltage rise

o Test 3

- Adjusted the temperature control on the hot tub to 100 degrees

- Exercised load controller manually

- Checked FC for spike that might cut inverter out

- Saw no problems

- Nick from Gaia

- After bringing power in from the fuel cell, the new APC UPS for the Gaia controller was resetting. It was removed and the controller was hooked to the surge suppressor output of the original remaining UPS. (full transfer load-size tracking will be disabled while Gaia controller not on UPS)

- As of 2:36 PM, running FC as battery charger

o Fuel cell outputting $2 \mathrm{~kW}$

- Power Tower taking in power on AC1 from FC

- Departed 2:45 PM

\section{9/13/2005}

Schneider, Morawski (Plug Power)

- $\quad$ Arrived 8:30 AM 
- Morawski got ModBus connection working on fuel cell

- Departed 11:30 AM

\section{$10 / 05 / 2005$}

Sackett, Pietrantoni

- Reset power to communications rack

- Checked propane level $\sim 30 \%$

\section{$\underline{10 / 10 / 2005}$}

Schneider

- Arrived 8:00 AM

- Powered down Gaia controller

- Waited 1 minute

- Power back up Gaia controller

\section{$10 / 31 / 2005$}

Schneider

- Checked on FC status, which was powered down upon Schneider's arrival

- Checked battery voltage of 30.5 Volts

\section{$11 / 02 / 2005$}

Reed, Pietrantoni, Schneider

- Charged upper 2 batteries in FC both to 11.9 Volts

- Re-connected all batteries

- Pressed start on fuel cell 10:44 AM

- FC entered manual mode 10:50 AM

- Through service interface, issued command "grid charge"

- FC shut down due to low voltage

- Put charger on lower left battery and then realized we had connected the terminals backwards on one of the batteries so we reconnected the terminals correctly

- Started FC again

- Set modem answer to 1 ring to facilitate Plug Power dial-in to FC

- Called Plug tech support and had them dial in

- Left site 11:50 AM

\section{$\underline{11 / 03 / 2005}$}

Schneider

- Arrived 9:15 AM

- Purge sample propane sample point downstream of propane meter, connect vacuum cylinder, open valve inlet on cylinder, sample for 2 minutes, close valve, remove cylinder 
- Tape empty/dry plastic water bottle on sampling point, allow propane to purge the contents of the plastic bottle for a minute or two

- Take 2 stain tube samples from the plastic bottle

- Stain tube results:

o $5 \mathrm{ppm}$

- Took cylinder back to office to prep for shipping

- Left site 10:00 AM

\section{$11 / 14 / 2005$}

Reed, Pietrantoni

- Arrived 9:00 AM

- Changed desulphurization bed and air filter on FC

- Left fuel cell in the off-state per Mark S.

- Departed 10:30 AM

\section{$11 / 15 / 2005$}

Schneider

- Arrived 9:30 AM

- Pressed FC start button to engage fans and SARC

- Left site $\sim 10: 15$

\section{$11 / 16 / 2005$}

Schneider

- Arrived 7:45 AM

- Used Mirabito gas leak detector

- Followed gas line into FC to desulf tank and out of desulf tank

- 8:00 AM put unit into startup mode

- Set number of modem rings to 1

- Returned gas leak detector to Mirabito

- Came back to check on FC around 8:45 AM - startup sequence looking good

- Had one shutdown event during startup due to insufficient fuel purging desulf tank

- Vinny from Plug remotely restarted and everything went fine

\section{$11 / 22 / 2005$}

Schneider

- Arrived $\sim 8: 45$ AM

- Pushed start button

- Plugged computer into serial port on FC

- Cleared PDC shutdown messages

- Commanded startup 9:00 AM

- Checked dual node power quality equipment

- Data node portion showing normal heartbeat on power LED

o Info node portion showing fast heartbeat 


\section{$11 / 16 / 2005$}

Schneider

- Arrived $\sim 4: 45 \mathrm{PM}$

- Put 1.5 kW heater in main FC compartment and ran extension cord to house power

- Power down FC

- Left site 5:00 PM

\section{$11 / 30 / 2005$}

Reed, Sackett, Schmitz, Schneider

- Took apart desulf bed connections

- Cleaned connections

- Re-taped with Teflon

- Reconnected

- Found wear on gas line outlet from desulf tank (5 psi fuel gas pipe trac pipe) where rubbing against blower

- Taped with electrical tape to prevent further wear

- Powered up unit $~ 10: 20$ AM

- Set rings to 1 and put into startup

- 11:20 AM FC shut itself down (error HW ESTOP TCO 01 PRE7 FG4 L1)

\section{$12 / 05 / 2005$}

Schneider, Pasquale (Gaia)

- Performed voltage drop tests on Power Tower

\section{$12 / 20 / 2005$}

Reed, Pietrantoni, Schneider

- Performed leak test with combustible gas detector and soapy water

- Unable to identify specific location of leak in reformer of FC

\section{$01 / 12 / 2006$}

Pietrantoni, Sackett, Schneider

- Arrived 11:30 AM

- Replaced desulf tank

- Checked for split rings on top/bottom of desulf tank

- Used 2 crescent wrenches to tighten connections

- Noted that the tank, which we just received, was dented in multiple locations and scratched and that the lower tank handle on desulf tank was bent

- $\sim 11: 45$ put FC in manual mode

- Manually opened solenoid $1 \mathrm{AB}$ (fuel solenoid)

- FC E-stopped within 2 minutes of solenoid $1 A B$ being opened

- Put FC in manual mode again

- Soaped up junction points in fuel line

- Opened Solenoid $1 \mathrm{AB} \sim 12: 20 \mathrm{PM}$ 
- No bubbles in the soapy water

- Gas leak detector made some noise at the other end of the 6" hose connecting to the solenoid, but no bubbles indicating a leak

- Put FC in startup 12:50 PM

\section{$01 / 17 / 2006$}

Reed, Pietrantoni, Morawski (Plug)

- Arrived 9:00 AM

- Changed out desulf tank and rechecked connections

- Pietrantoni left site $\sim 11 \mathrm{AM}$

- Morawski installed new software on FC

- Checked a few other items and started fuel cell

- Left site at 12:38 PM with the FC in startup mode with Plug tech support monitoring via modem

\section{1/19/2006}

Reed, Schneider

- Arrived on site 2:30 PM

- Plugged space heater in to protect against freezing during shutdowns

- Noted FC was shut down

- Checked phone line at fuel cell with analog phone line by making phone a local phone call - phone line was fine

- Called Morawski at Plug - he dialed in and put FC into startup mode

- Left site $\sim 3: 00$ PM

\section{$02 / 14 / 2006$}

Reed, Pietrantoni, Schneider, M. Simonds, D. Simonds

- Simonds ran hot tub ckt into $1^{\text {st }} 200 \mathrm{Amp}$ breaker panel and routed around the load control relays

- Ran new basement receptacles into main house panel empty breaker location

- Adjusted orientation on satellite dish such that modem reported signal strength at 73 from a prior value of 50

- Added small amount of therminol to FC coolant reservoir

- Connected laptop to serial port on FC

- Changed \# modem rings to 1

- Called Rob at Plug Power and had him dial in

- Set fan voltage to 0.9 Volts

- Set low power output setting to $2 \mathrm{~kW}$

- Changed \# modem rings back to 8

- Chris and Ib from Gaia confirmed that load controls now routed around

- 11:14 AM switched transfer switch out of manual over-ride to automatic mode using the toggle switch on the Gaia controller

- Noticed a noise coming from the hot water heat exchanger

- Switched back to manual over-ride

- Noticed that noise continued 
- Switched one last time back to auto mode

- Confirmed that the hot tub was heating correctly

\section{$03 / 22 / 2006$}

Schneider, Todd (Gaia)

- Performed series of tests with step loads to analyze voltage dip (short term flicker) issue

- Used Picoscope 3000 (www.picotech.com) with M1053 differential probes

- With the power tower and transfer switch in manual bypass mode, AC1 (from FC) open, and AC2 (from grid) closed, performed experiment A to establish baseline voltage dip in the presence of large switching loads in home

o Turned oven on 450 degrees $F$

o Turned 2 large burners on stove top

o Turned microwave on for 30 seconds and then off

o Recorded 126.3 Volts max and 121.7 Volts minimum during experiment $A$ monitoring AC2 input to Power Tower

- With the Power Tower and transfer switch still in manual bypass mode, AC1 closed, and AC2 closed, performed experiment B1

o Oven set at 450 degrees $F$

o Well pump kicked on and off

o Recorded 121.8 Volts max and 118.3 Volts minimum during experiment B1 monitoring AC1 input to Power Tower

- With the Power Tower and transfer switch still in manual bypass mode, AC1 closed, and AC2 closed, performed experiment B2

o Oven set at 450 degrees $F$

o Turned 2 large burners on stove top

o Turned microwave on for 30 seconds and then off

o Recorded 121.8 Volts max and 116.4 Volts minimum during experiment B2 monitoring AC1 input to Power Tower

- Took Power Tower and transfer switch out of manual bypass mode and put it in auto mode

- Now transfer switch passing power from Power Tower to main house panel

- With the Power Tower and transfer switch in auto mode, AC1 closed, and AC2 closed, performed experiment $\mathrm{C}$

o Oven set at 450 degrees $\mathrm{F}$

o Turned 2 large burners on stove top

o Turned microwave on for 30 seconds and then off

o Recorded 122.6 Volts max and 112.9 Volts minimum during experiment C monitoring output of Power Tower

- With the Power Tower and transfer switch in auto mode, AC1 open, and AC2 closed and locked on, performed experiment $D$

o Oven set at 450 degrees $F$

o Turned 2 large burners on stove top

o Turned microwave on for 30 seconds and then off

o Recorded 126.1 Volts max and 120.3 Volts minimum during experiment $D$ monitoring output of Power Tower 
- Killed the grid input to everything on site

- With the Power Tower and transfer switch in auto mode, AC1 open, and AC2 unavailable, performed experiment $\mathrm{E}$

- Oven set at 450 degrees $F$

o Turned 2 large burners on stove top

o Turned microwave on for 30 seconds and then off

o Recorded 120.1 Volts max and 112.3 Volts minimum during experiment $E$ monitoring output of Power Tower

- To synchronize real-world time with the timestamps on the data recording equipment and the time stamp in the Gaia controller, a final 30-second cycle on the microwave was performed at 3:29 PM on Chris's cell phone

- $\quad 4$ PM met with home owner Randy Tweedie to look at light dimming symptoms

- Chris Todd was able to see the same symptoms as Tweedie

- Symptoms were most obvious when turning loads on and off

- Direct connected PC to FC and reset the setpoint to "2" before leaving

- Left site $\sim$ 4:35 PM

\section{$03 / 28 / 2006$}

Reed, Pietrantoni, Schneider

- Replaced gas sensor and air sensor

- Restarted FC

\section{$\underline{04 / 27 / 2006}$}

Schneider

- Connected PC to FC

- Completely powered down FC

- Re-powered FC

- Started Plug maintenance application on the PC

- Put unit in startup 1:37 PM

\section{5/02/2006}

Remotely Ib and Edvin (Gaia)

- Late afternoon did a remote software upload and rebooted Gaia controller

\section{5/10/2006}

Reed, Pietrantoni, Schneider

- Powered down FC

- Replaced prox air solenoid

- 2:05 PM powered up FC

- 2:19 PM put FC into startup mode

- Visual inspection of all equipment in utility room of home

- New hot water heat exchanger controller has been installed by home owner's contractor

\section{$\underline{05 / 20 / 2006}$}


Randy Tweedie (homeowner)

- Switched bypass switch so that main panel is directly grid-fed in response to power quality issues in home

\section{$\underline{05 / 25 / 2006}$}

Schneider

- Cycled power on VPN router, in-house network router, and Gaia widget

- Called DCEC office and had Alain check the real-time data access to the site

- Real-time data is working fine after reboots of network equipment

\section{$\underline{06 / 07 / 2006}$}

Reed

- Did a visual inspection of propane tank

- Tank gauge read $40 \%$ full

- Pressure gauge downstream of propane meter not functioning

\section{$06 / 08 / 2006$}

Reed

- Did a visual inspection of propane tank

- Tank gauge read $40 \%$ full

- Made no changes to valve positions

- Pressure gauge downstream of propane meter read $\sim 12$ inches of water

\section{$06 / 12 / 2006$}

Schneider

- Arrived 4:35 PM

- Did a visual inspection of propane tank

- Tank gauge read $40 \%$ full

- Pressure gauge downstream of propane meter not functioning

- Closed T-valve to pressure gauge, removed gauge, blew into open feed to gauge causing needle to move

- Briefly opened T-valve to confirm positive pressure in fuel line and heard/smelled gas coming out of the opening where gauge is normally attached

- Re-attached gauge to propane piping, opened T-valve, and read 12.5 inches of water

- Put fuel cell into startup mode

- Startup seemed normal

- Left site 5:00 PM

\section{$07 / 26 / 2006$}

Schneider, Dave (Eastmount Environmental)

- Arrived 7:45 AM

- Ran 4 power cords to portable test lab 

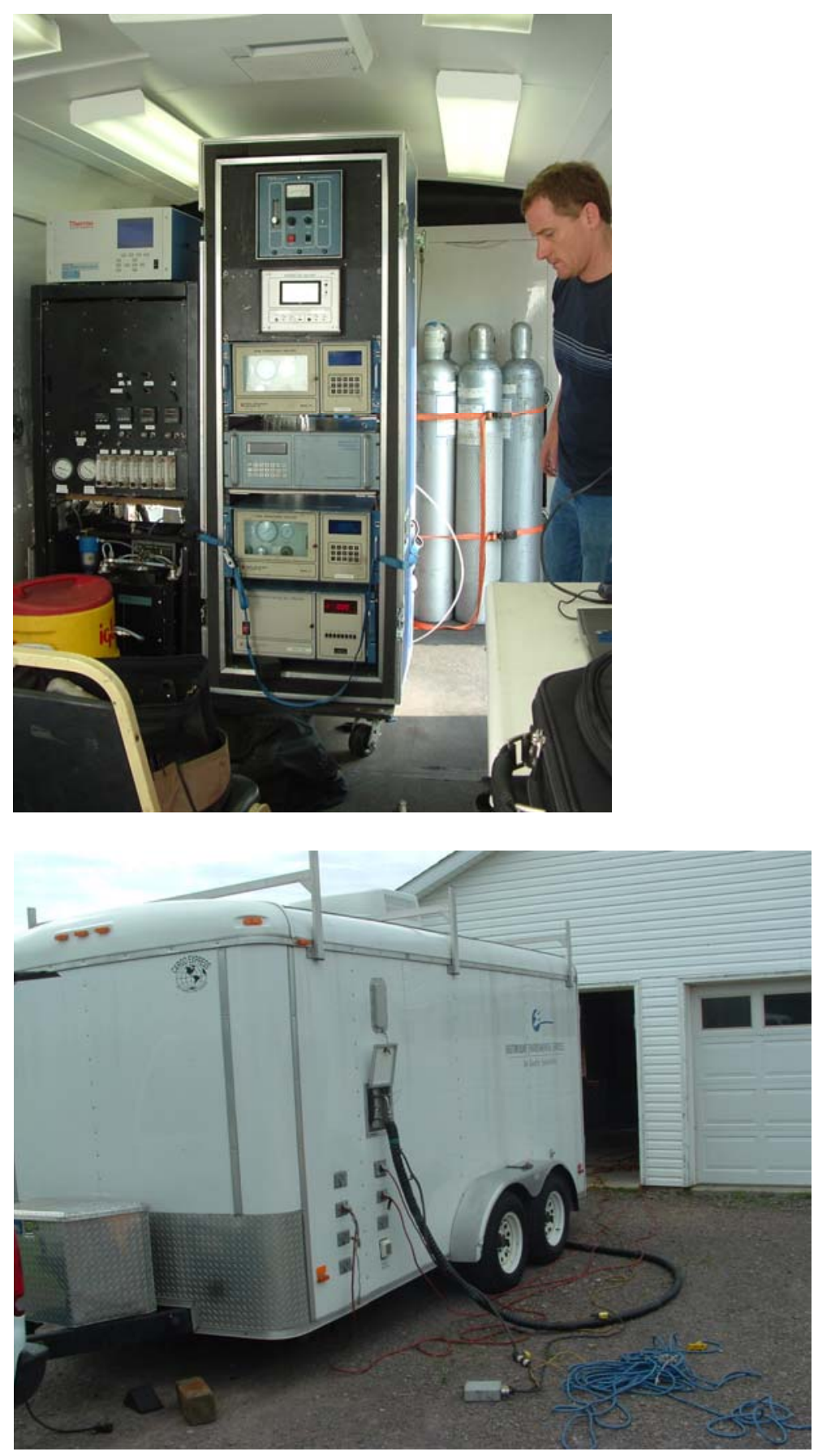

- Used stainless piping to create a probe for FC stack 


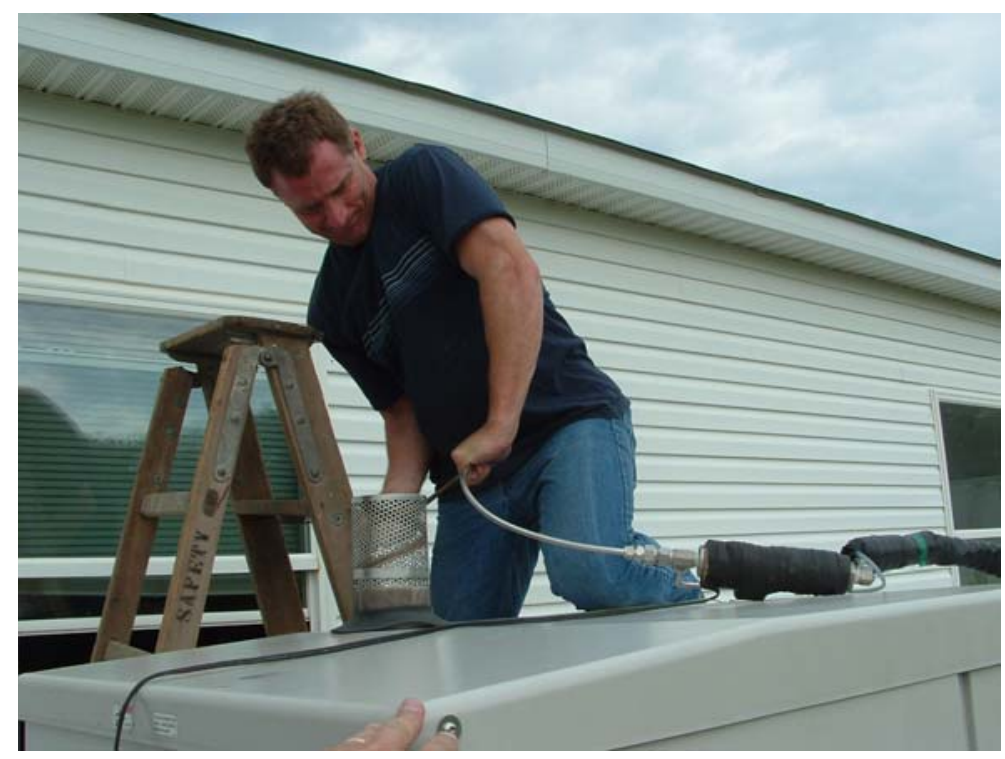

- Powered on FC 8:55 AM

- Checked comms with FC good

- Removed FC stack cover and inserted test probe into stack after checking for possible interference of fan by probe

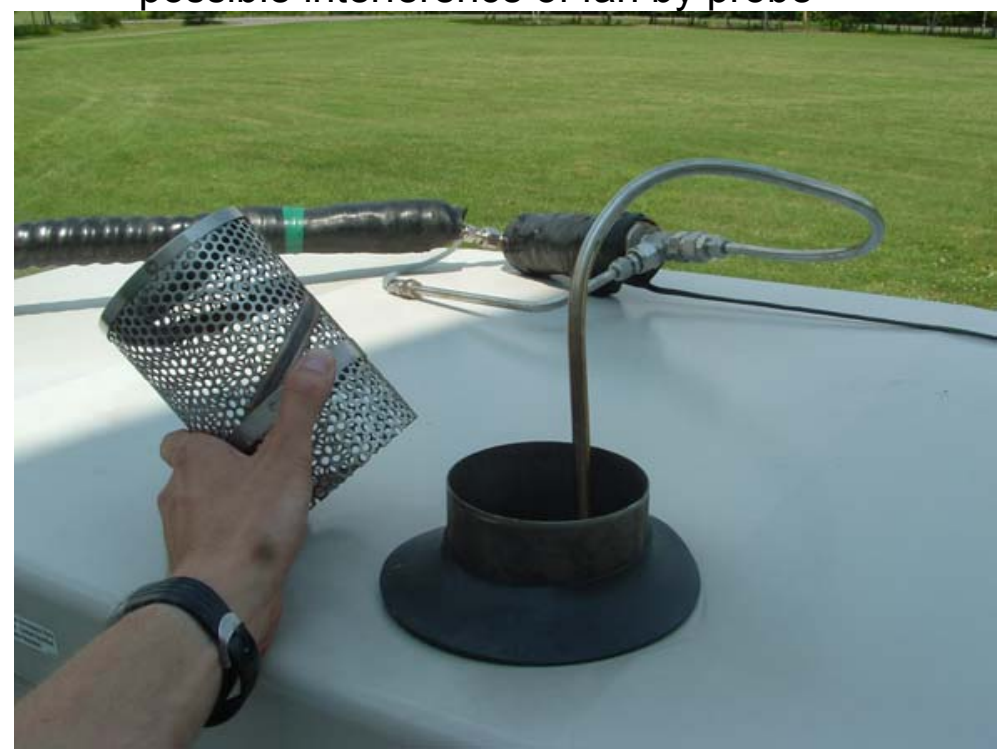

- Checked for leaks, then vacuum in test line

- 2:30 AM began calibration of test gear with calibration gases Dave brought with him

o First ran gases directly into instrument

o Then ran calibration gases through loop including the entire tube from the test probe back to the test lab 


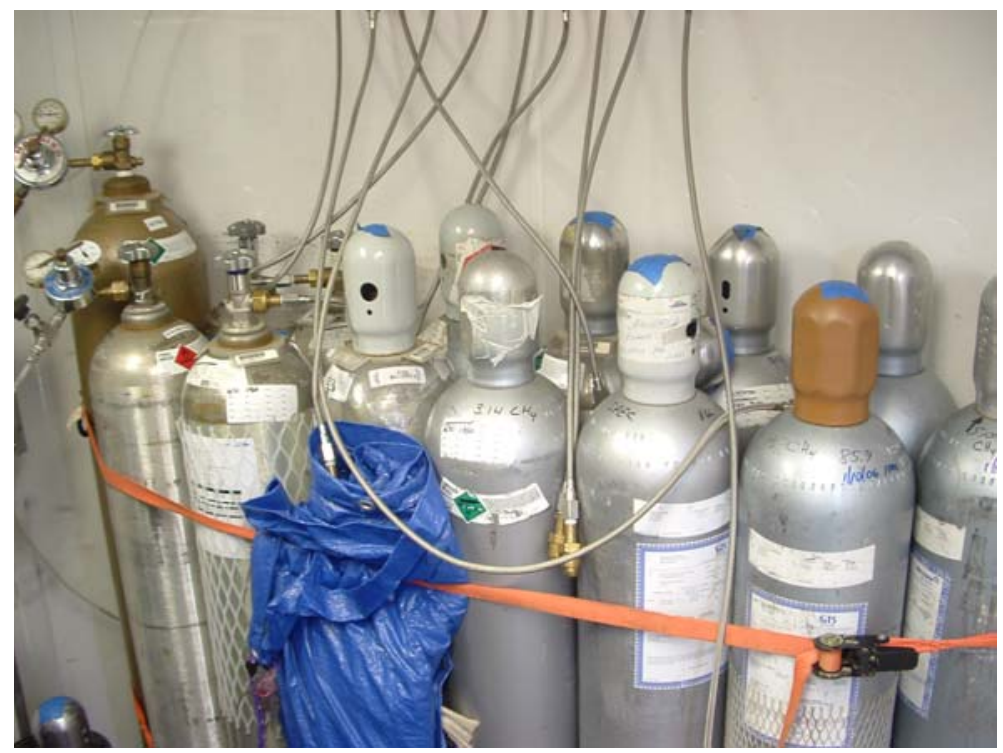

- Note that sketch of test lab calibration and test setup is available in the original site log, but it was not duplicated in this appendix in the interest of time

- Data was sampled every 2 seconds and averaged over 30 samples such that 1minute averages are recorded in the electronic data log

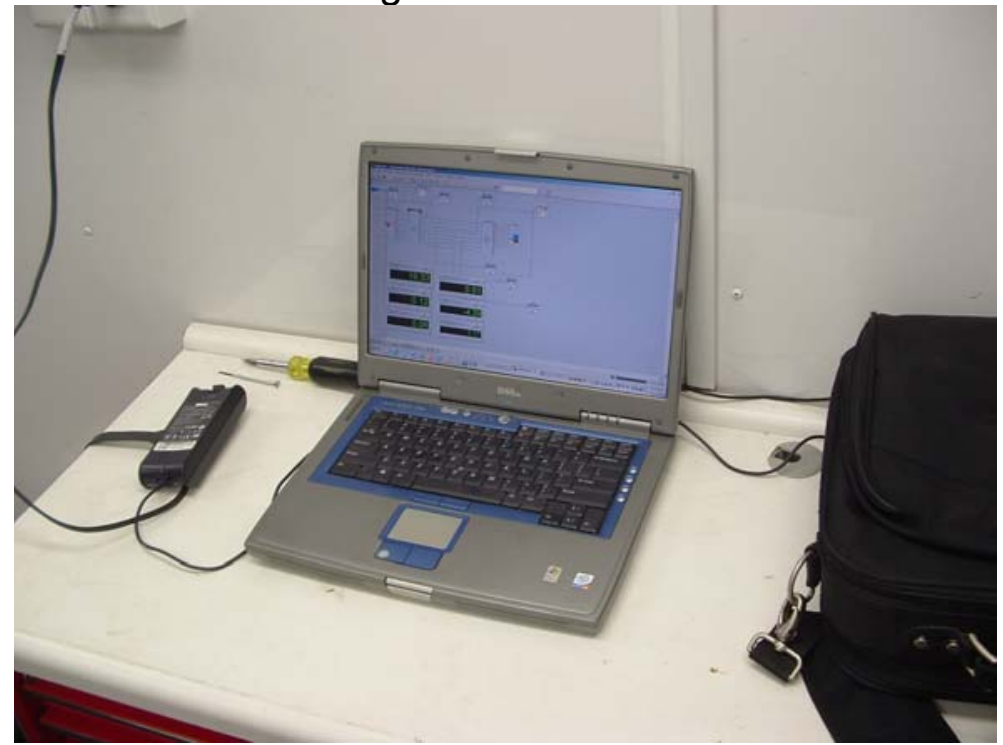

- Started up FC at 10:07 (time per Schneider wrist watch, which is 2 minutes ahead of Eastmount system time of 10:05)

o Sys state $=$ reformer purge, $\mathrm{FC}$ state $=$ ref scr warmup, Reformer state $=$ drain LTS

- At 10:08 AM, reformer state changed to DI fill

- Dave measured the inside diameter of the FC exhaust stack to be 4 inches and set up pito tube for flow measurements in the exhaust stream

- Discovered that a FC solenoid was freezing open that was preventing the fuel cell humidifier vessel from filling all the way

- Between 1:09 and 1:15 PM we removed the solenoid and capped off the tube so that the humidifier vessel could complete its fill operation 
- $\sim 1: 30$ PM the Reformer state changed to ATO flow

- $\sim 1: 31$ PM the Reformer state changed to Purge state

- $\quad$ 13:29 (Eastmount system time) on Dave's data we noted that the total hydrocarbons peaked above $100 \mathrm{ppm}$ range, so Dave switched to the 1000 PPM scale. We may have lost 1 or 2 minutes of THC data in transition between 0-100 PPM range and 0-1000 PPM range.

- Between 1:40 and 1:45 PM took flow measurements in the stack

o 87 degrees

o 29 molecular weight assumed

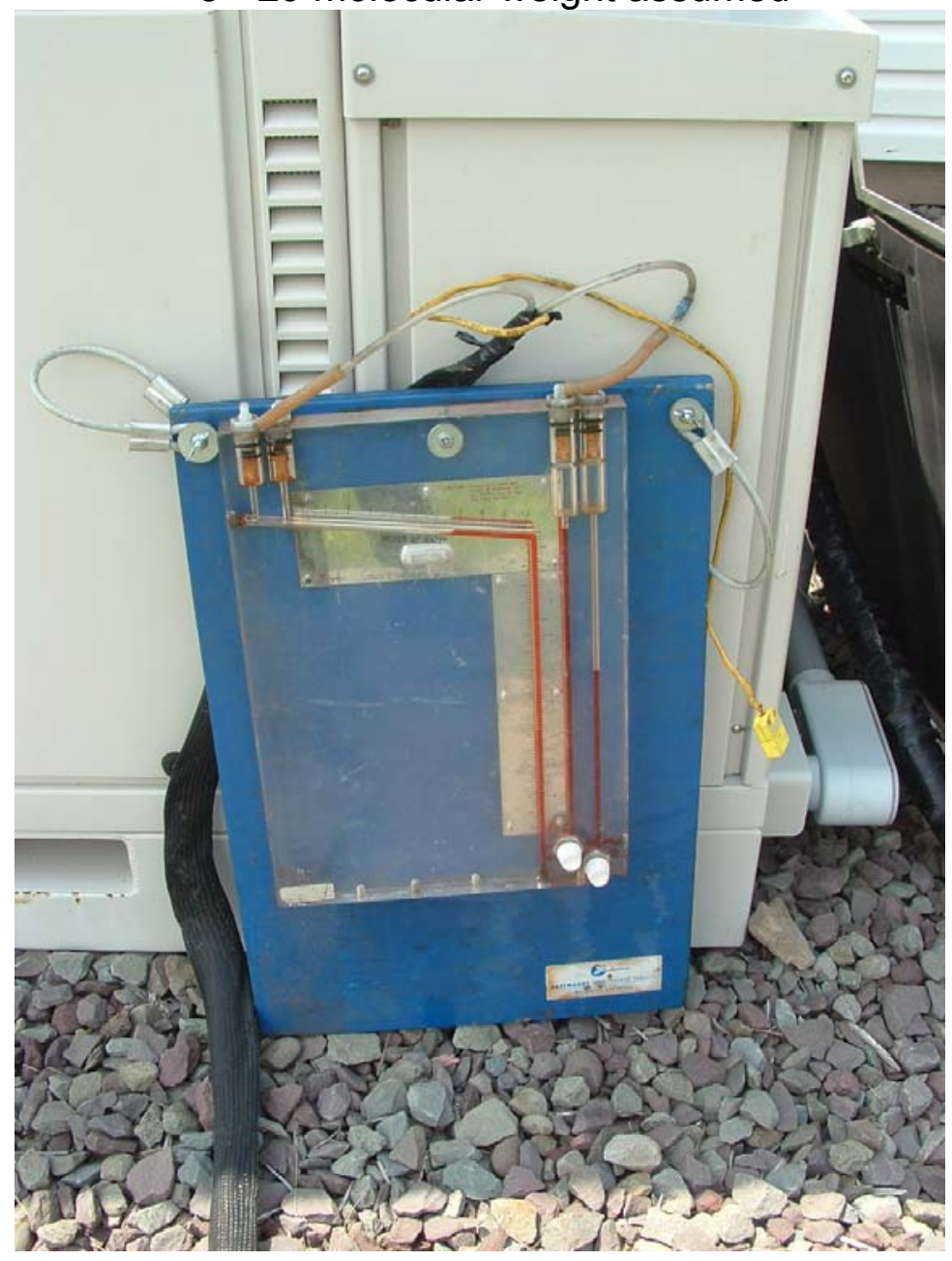




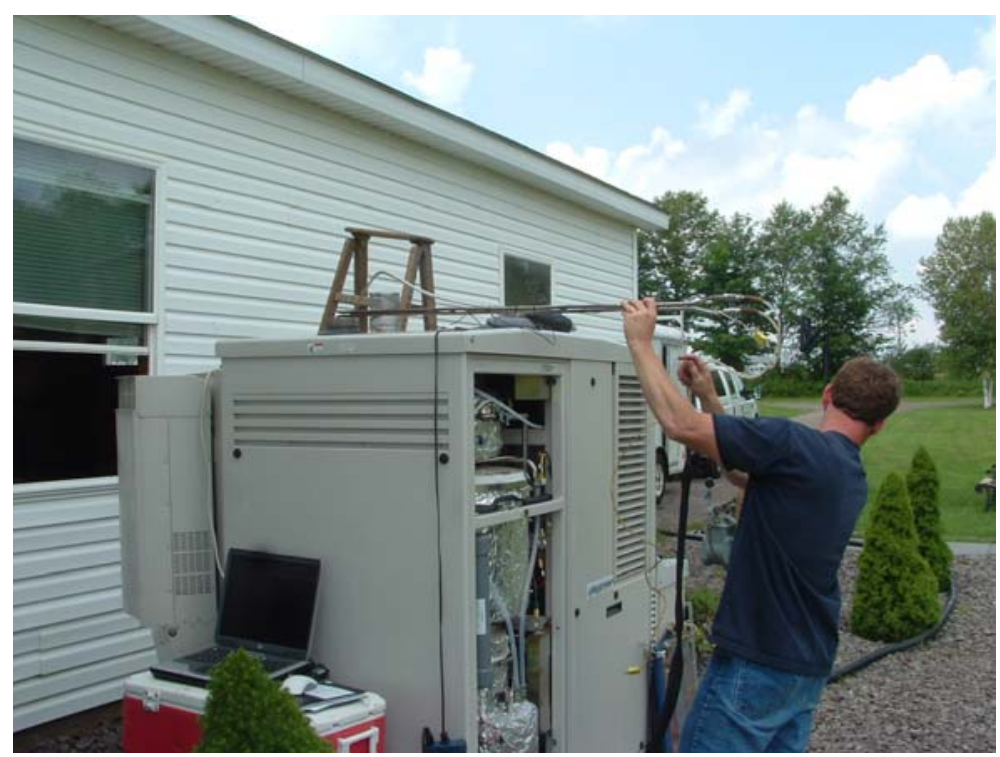

- Validated flow measurement with separate S-type flow measurement device

- Stack temperature at 3:02 PM was 150 degrees $F$

- 3:21 auto shutdown and restart by FC

- 3:23 PM manual shutdown by Schneider

- Dave re-ran system calibration

- Left site $\sim$ 4:00 PM

\section{$07 / 27 / 2006$}

\section{Pietrantoni, Schneider, Morawski (Plug)}

- Arrived 7:30 AM

- Powered up FC to get last event and stats logs

- Disconnected AC power at outdoor manual disconnect

- Morawski disconnected batteries

- Moved fuse to spare position

- Pietrantoni disconnected and partially drained the thermal protection for the water line

- Disconnected and partially drained the CHP loop

- Turned off propane at meter and tank

- Pietrantoni disconnected propane from FC

- Morawski removed catalyst, but it was still warm from running yesterday so he was a little worried about temperature 


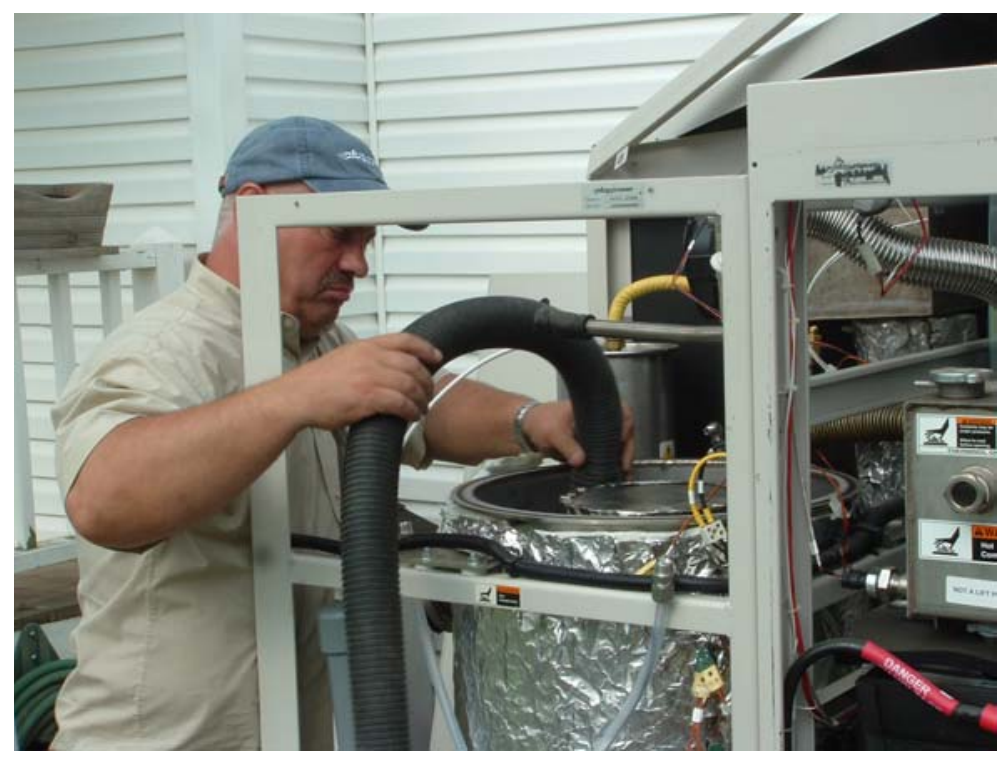

- Morawski removed the desulf tank

- Pietrantoni drained therminol

- Using boom truck, lifted FC to flat bed truck

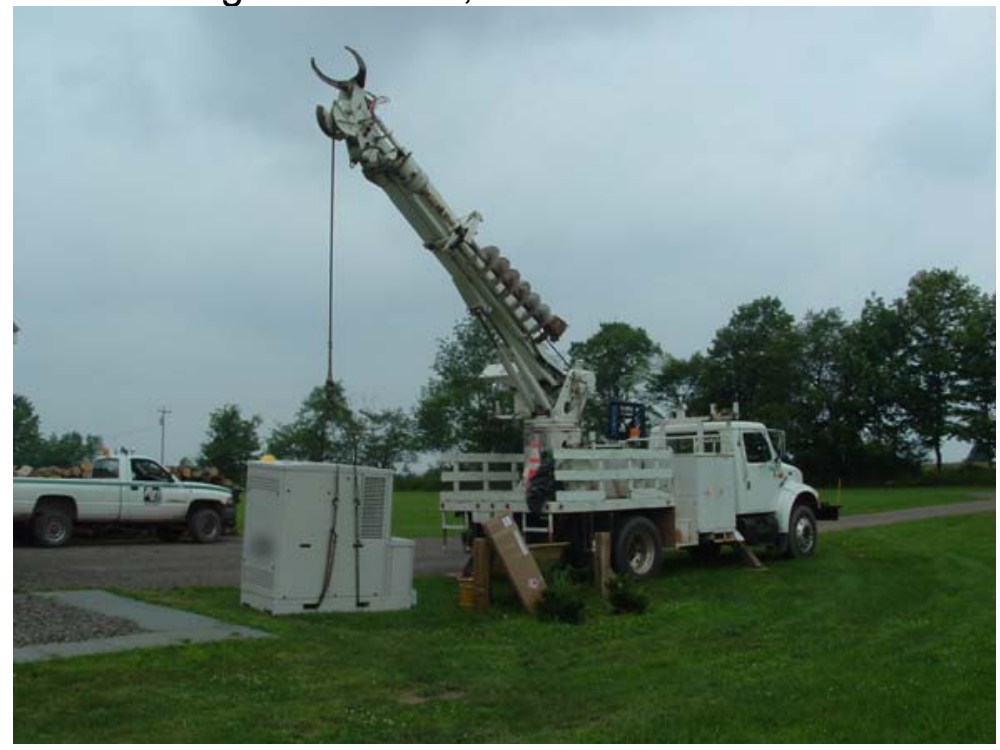

- Also placed hazardous materials in two containers on flat bed truck in front of FC

Note that the original site log book continues beyond 07/27/2006 and covers on-site work related to data collection equipment, communications gear, and energy storage equipment involved in a companion project to the fuel cell project. 
DE-FC36-04G014239

Delaware County Electric Cooperative, Inc.

\section{Appendix B - Fuel Cell Shutdown Log}

The table in Appendix B is a summary of the shutdown events that the fuel cell experienced during the 1-year demonstration period starting with the first full startup event on June 2, 2005.

\begin{tabular}{|c|c|c|c|c|}
\hline $\begin{array}{c}\text { Shutdown } \\
\text { Date }\end{array}$ & Description & $\begin{array}{c}\text { Affected } \\
\text { Subsystem }\end{array}$ & $\begin{array}{l}\text { Next Full } \\
\text { Startup* }\end{array}$ & $\begin{array}{l}\text { Mitigation } \\
\text { \& Repair } \\
\text { Notes }\end{array}$ \\
\hline $6 / 2 / 2005$ & Manual Shutdown & All & $6 / 16 / 2005$ & $\mathrm{~N} / \mathrm{A}$ \\
\hline $6 / 16 / 2005$ & Manual Shutdown & All & $6 / 21 / 2005$ & $\mathrm{~N} / \mathrm{A}$ \\
\hline $6 / 21 / 2005$ & $\begin{array}{l}\text { FC_CONTACTOR_RETRY_TIMEOUT } \\
\text { Low Cell Trip Alert } \\
\text { Inverter Communications }\end{array}$ & $\begin{array}{l}\text { Stack Health } \\
\text { Processor }\end{array}$ & $7 / 1 / 2005$ & $\begin{array}{l}\text { Replaced } \\
\text { main } \\
\text { processor } \\
\text { (SARC), } \\
\text { purged fuel } \\
\text { line }\end{array}$ \\
\hline $7 / 11 / 2005$ & Inverter Communications & Processor & $7 / 11 / 2005$ & $\begin{array}{l}\text { Auto } \\
\text { Restart }\end{array}$ \\
\hline $7 / 14 / 2005$ & Manual Shutdown & All & $7 / 14 / 2005$ & $\begin{array}{l}\text { Replaced } \\
\text { Inverter }\end{array}$ \\
\hline 7/15/2005 & Inverter Related & Inverter & $7 / 26 / 2005$ & $\begin{array}{l}\text { Manual } \\
\text { Restart }\end{array}$ \\
\hline $7 / 27 / 2005$ & TC10_ATO_1_LOW_SD,310 & $\begin{array}{l}\text { Anode Tail } \\
\text { Gas } \\
\text { Oxidation } \\
\text { Module }\end{array}$ & $7 / 27 / 2005$ & $\begin{array}{l}\text { Auto } \\
\text { Restart }\end{array}$ \\
\hline $7 / 28 / 2005$ & LOW_CELL_TRIPS_MAXED_SD,502 & Stack Health & $8 / 1 / 2005$ & $\begin{array}{l}\text { Replaced } \\
\text { stack }\end{array}$ \\
\hline $8 / 2 / 2005$ & TC10_ATO_1_LOW_SD,310 & $\begin{array}{l}\text { Anode Tail } \\
\text { Gas } \\
\text { Oxidation } \\
\text { Module } \\
\end{array}$ & $8 / 2 / 2005$ & $\begin{array}{l}\text { Auto } \\
\text { Restart }\end{array}$ \\
\hline $8 / 2 / 2005$ & STACK_COOL_OUTLET_LOW_ALERT,236 & $\begin{array}{l}\text { Low Stack } \\
\text { Temperature }\end{array}$ & $8 / 3 / 2005$ & $\begin{array}{l}\text { Replaced } \\
\text { inverter } \\
\text { (again) }\end{array}$ \\
\hline $8 / 24 / 2005$ & O2_CH4_HIGH_SD,512 & Reformer & $8 / 24 / 2005$ & $\begin{array}{l}\text { Auto } \\
\text { Restart }\end{array}$ \\
\hline $10 / 26 / 2005$ & STACK_COOL_INLET_LOW_SD, 240 & $\begin{array}{l}\text { Low Stack } \\
\text { Temperature }\end{array}$ & $10 / 26 / 2005$ & $\begin{array}{l}\text { Auto } \\
\text { Restart }\end{array}$ \\
\hline $11 / 2 / 2005$ & HW_ESTOP_FG1_L5, 531 & $\begin{array}{l}\text { Hardware E- } \\
\text { stop }\end{array}$ & $11 / 2 / 2005$ & $\begin{array}{l}\text { Charge } \\
\text { Batteries } \\
\text { and correct } \\
\text { battery } \\
\text { breaker } \\
\text { position }\end{array}$ \\
\hline
\end{tabular}


DE-FC36-04G014239

Delaware County Electric Cooperative, Inc.

\begin{tabular}{|c|c|c|c|c|}
\hline $\begin{array}{c}\text { Shutdown } \\
\text { Date }\end{array}$ & Description & $\begin{array}{c}\text { Affected } \\
\text { Subsystem }\end{array}$ & $\begin{array}{l}\text { Next Full } \\
\text { Startup* }\end{array}$ & $\begin{array}{c}\text { Mitigation } \\
\text { \& Repair } \\
\text { Notes }\end{array}$ \\
\hline $11 / 14 / 2005$ & $\begin{array}{l}\text { Manual Shutdown for desulf tank change- } \\
\text { out and air filter replacement }\end{array}$ & All & $1 / 19 / 2006$ & $\begin{array}{l}\text { Multiple } \\
\text { propane } \\
\text { leak tests, } \\
\text { replaced } \\
\text { desulf tank, } \\
\text { Plug } \\
\text { installed } \\
\text { new } \\
\text { software }\end{array}$ \\
\hline $1 / 20 / 2006$ & O2_CH4_HIGH_SD, 512 & Reformer & $1 / 20 / 2006$ & $\begin{array}{l}\text { Auto } \\
\text { Restart }\end{array}$ \\
\hline $2 / 17 / 2006$ & O2_CH4_HIGH_SD, 512 & Reformer & $2 / 17 / 2006$ & $\begin{array}{l}\text { Auto } \\
\text { Restart }\end{array}$ \\
\hline $2 / 28 / 2006$ & STACK_COOL_INLET_LOW_SD, 240 & $\begin{array}{l}\text { Low Stack } \\
\text { Temperature }\end{array}$ & $2 / 28 / 2006$ & $\begin{array}{l}\text { Auto } \\
\text { Restart }\end{array}$ \\
\hline $3 / 28 / 2006$ & HW_ESTOP_SARC_L0, 534 & $\begin{array}{l}\text { Hardware E- } \\
\text { stop }\end{array}$ & $3 / 28 / 2006$ & $\begin{array}{l}\text { Replaced } \\
\text { gas sensor } \\
\text { and air } \\
\text { sensor }\end{array}$ \\
\hline $4 / 20 / 2006$ & O2_CH4_HIGH_SD, 512 & Reformer & $4 / 20 / 2006$ & $\begin{array}{l}\text { Auto } \\
\text { Restart }\end{array}$ \\
\hline $4 / 27 / 2006$ & HW_ESTOP_SARC_L0, 534 & $\begin{array}{l}\text { Hardware E- } \\
\text { stop }\end{array}$ & $4 / 27 / 2006$ & $\begin{array}{l}\text { Manual } \\
\text { Restart }\end{array}$ \\
\hline $5 / 3 / 2006$ & O2_CH4_HIGH_SD, 512 & Reformer & $5 / 3 / 2006$ & $\begin{array}{l}\text { Auto } \\
\text { Restart }\end{array}$ \\
\hline $5 / 10 / 2006$ & HW_ESTOP_SARC_L0, 534 & $\begin{array}{l}\text { Hardware E- } \\
\text { stop }\end{array}$ & $5 / 10 / 2006$ & $\begin{array}{l}\text { Replaced } \\
\text { Prox air } \\
\text { solenoid }\end{array}$ \\
\hline $6 / 5 / 2006$ & O2_CH4_HIGH_SD, 512 & Reformer & $6 / 12 / 2006$ & $\begin{array}{l}\text { Manual } \\
\text { Restart }\end{array}$ \\
\hline $7 / 5 / 2006$ & HW_ESTOP_SARC_L0, 534 & $\begin{array}{l}\text { Hardware E- } \\
\text { stop }\end{array}$ & N/A & N/A \\
\hline
\end{tabular}

*The term "full startup" is used to indicate that the system, fuel cell, and reformer are all in their running states. It was not uncommon for the fuel cell to abort a startup attempt and either auto-restart or require a manual restart. The shutdown events in this table are those shutdown events that follow a full startup. If a startup event was not fully successful, that startup event is not shown in this Appendix. 